\title{
West African Goldfields
}

\author{
M. Robertson ${ }^{1}$ and L. Peters ${ }^{2}$ \\ The MSA Group, 20B Rothesay Avenue, Craighall Park, 2196, South Africa \\ E-mail:miker@msagroupservices.com ${ }^{1}$; lukep@msagroupservices.com ${ }^{2}$
}

DOI: 10.18814/epiiugs/2016/v39i2/95773

The West African region has long been known for its gold endowment and gold production. Apart from the last 20 to 30 years, this production was largely derived from informal artisanal workings covering large areas of West Africa. For a period of over a thousand years until 1500 AD, West Africa was the world's most important supplier of gold, much of which formed part of the trans-Sahara trade with the Arab world, whose monetary system was based on gold. Artisanal gold mining is still widespread across West Africa and a significant number of modern gold mines in the region were founded on artisanal mining sites.

Aided by regional mapping and geochemical programmes by geological surveys and the UNDP, as well as the dramatic rise in the gold price between 2001 and 2011, the West African region has seen a rapid expansion in gold exploration activity over the last two decades. This resulted in the establishment of new mines in Mali, Burkina Faso, Côte d'Ivoire, Ghana, Senegal and Guinea.

The West African Craton is composed of Archaean and Palaeoproterozoic rocks which are generally poorly exposed due to deep weathering. While gold mineralisation is known in the Archaean, most gold deposits and occurrences in the region are hosted in a wide range of rock types, from volcanic to turbiditic metasedimentary sequences, which form part of the Palaeoproterozoic Birimian Supergroup. The majority of deposits are of orogenic-type, however gold also occurs in intrusion-related deposits, skarn deposits and as palaeoplacer deposits.

Large parts of the West African region remain underexplored relative to similar gold provinces elsewhere. Apart from the Kibali deposit in the northeastern Democratic Republic of Congo (DRC), the West African region leads the continent in terms of recent gold exploration focus and discovery, and the region is still considered largely prospective and relatively immature from an exploration perspective.

\section{Introduction}

The gold potential of West Africa has long been known, with informal artisanal mining having taken place for centuries. However, modern systematic exploration and commercial scale mining have only come into their own relatively recently. Ghana has long been the second largest gold producer on the African continent after South Africa, having produced 2.85 million troy ounces (Moz) in 2013. The increasing importance of West Africa as a gold producing region is reflected in Mali and Burkina Faso which have become the third and fifth largest African producers respectively, the former having yielded 1.42 Moz and the latter 0.77 Moz in 2013 .

The majority of gold deposits on the West African Craton are hosted in Palaeoproterozoic rocks of the Birimian Supergroup, and are temporally and spatially related to structures formed during the Eburnean Orogeny between $2200 \mathrm{Ma}$ and $2088 \mathrm{Ma}$ (e.g. Allibone $e t$ al., 2002; Perrouty et al., 2012). Birimian rocks cover a large part of the southern portion of the West African Craton and also occur as inliers within younger sequences. Consequently, known gold deposits and occurrences are located within an area of some 1.5 million $\mathrm{km}^{2}$, covering large parts of Ghana, Côte d'Ivoire, Burkina Faso, Mali, Senegal and Guinea.

West Africa is seen as an emerging gold producing region having attracted significant exploration interest and expenditure over the last two decades. Our understanding of the various gold deposit styles and geological settings, has been enhanced through this exploration impetus, as well as through parallel research programmes such as the West African Exploration Initiative (WAXI).

This contribution aims to provide a geological review of the West African Craton and a review of the main gold producing regions of West Africa, apart from Ghana, which is described in Smith et al. (this volume). Information pertaining to individual deposits was sourced from technical reports available in the public domain, company websites and submissions to a West African mineral deposits atlas.

\section{Early History and Events Leading to Discovery}

\section{Early History}

The importance of gold in West African history is well documented in numerous sources. The following account is sourced largely from Gewald (2010).

For at least 1500 years, gold has dominated the economy of the West African region. Between 400 and $1500 \mathrm{AD}$, West Africa was the world's most important supplier of gold. For the past 2000 years, agricultural communities have prospected and mined (mostly placer) gold in small, informal workings across an extensive area of West 
Africa, when the agricultural cycle allowed them to do so. In the early centuries $\mathrm{AD}$, trade routes across the Sahara to West Africa were established by Berber camel caravans, which came to dominate the trans-Saharan trade until the second half of the twentieth century. In essence, southbound salt was exchanged for northbound gold. West Africa contributed gold to the new trading links for some 1100 years from the early centuries $\mathrm{AD}$, and, until the European discovery of America, West Africa supplied the bulk of the world's gold production.

The Arab conquest of North Africa in the seventh century further opened the gold trade to the Arabs, whose monetary system was based on gold. According to the early tenth-century geographer Ibn al-Faqih, gold grew there 'in the sand, as carrots do, and is picked at sunrise'.

Ancient Ghana was the focus of the gold trade for approximately 800 years until its collapse in the early 1200 s. The early fourteenth century represented the golden age of Mali, whose empire came most dramatically to the attention of the world during the reign of Mansa Musa (1312-1337), the most famous of the Mali rulers. It was Mansa Musa's pilgrimage to Mecca in 1324 that literally put Mali on the map. During his stay in Egypt on his way to Mecca he "spent and gave away so much gold that there was a major devaluation of the local currency".

The lure of West African gold drove the Portuguese voyages of exploration from the fifteenth century. The system of informal mining of gold and the trading thereof remained in existence and only changed in the $20^{\text {th }}$ century, with the introduction of financed industrial mining enterprises.

\section{Modern History}

An "orderly commercial approach to mining" of gold in West Africa began in the late $19^{\text {th }}$ century (Ayensu, 1997), initially targeting palaeo-placer deposits, and later quartz vein and lode gold mineralisation. Artisanal mining of gold continues to be widespread across West Africa, and a significant number of gold mines currently operating in West Africa were founded on historical or existing artisanal mining sites.

The past almost 100 years of geological research on the West African Craton is summarised in Jessell and Liégeois (2015). Investigations commenced prior to 1920 with systematic geological mapping by Henry Hubert, a French Government official working in French West Africa. Hubert's work culminated in the 1934 publication of the 1:6 million regional map (Hubert, 1934), that first shows the recognisable geological units observed on today's maps.

Major regional mapping and geochemical surveys by the United Nations Development Programme (UNDP) and geological surveys, including the Bureau de Recherches Géologiques et Minières (BRGM) in the late 1970s and early 1980s, laid the foundation for the drive in gold exploration over the last two decades. This witnessed a rapid expansion in mineral exploration in West Africa, largely driven by changes in the political climate, fiscal and legal regimes, exploration approaches and increased understanding of West African geology (Pohl, 1998). An additional driving impetus was the discovery by native artisanal miners of many significant new gold occurrences throughout the region (Pohl, 1998).

The successful democratisation and evolution from military regimes to multiparty governments in some West African countries, has led to a more mature political climate, conducive to investment in mineral exploration and mining, particularly by foreign entities. Ghana led the way in 1986 with major positive changes in mining law and fiscal regimes covering the mining industry and this was followed by progressive changes to mining legislation in other countries in the region. Mining and tax legislation is now generally in line with that of more developed countries and in many instances, countries offer favourable tax treatment to the mining industry.

The relatively recent gold exploration impetus was largely driven by the recognition that large parts of West Africa are underlain by deeply weathered regolith cover, similar to Australia, thereby lending itself to airborne geophysical surveys and deep geochemical sampling such as rotary air blast (RAB) drilling. Numerous discoveries and a number of new mines have been made over the recent past, perhaps nowhere more so than in the Kédougou Kéniéba Inlier which straddles Mali and Senegal, where over 35 million new ounces of gold have been delineated in the last 20 years.

Significant recent discoveries, based on modern systematic exploration, have also been made in southern Mali, the eastern half of Burkina Faso and parts of Côte d'Ivoire. Apart from the Kibali deposit in the northeastern DRC, the West African region leads the continent in terms of recent gold exploration focus and discovery, and the region is still considered largely prospective and relatively immature from an exploration perspective.

The West African region has been the subject of intense geological research through the AMIRA International WAXI programme since 2006. The overall aim of the WAXI is to enhance the exploration potential of the West African Craton through an integrated programme of research and data gathering, and to augment the capacity of local institutions to undertake this type of work. This research has culminated in numerous theses and publications, including special issues of the Journal of African Earth Sciences, Ore Geology Reviews, Precambrian Research and Economic Geology.

\section{Regional Geological Framework}

The West African Craton extends across 14 countries in western Africa (Jessell and Liégeois, 2015) and is composed of Archaean and Palaeoproterozoic rocks that cover a surface area of approximately 4.5 million $\mathrm{km}^{2}$, as shown by the craton outline in Figure 1. The boundaries of the craton are largely defined by a combination of surface geology and gravity signatures (Ennih and Liégeois, 2008a, b). However, exposure of these rocks throughout the region is generally poor, due to deep weathering. The craton comprises two Precambrian shield areas composed of Archaean domains, namely the Reguibat Shield in the north and the Kénéma-Man domain in the south, both separated from Palaeoproterozoic domains to the east by major shear zones.

The Archaean Reguibat and Kénéma-Man shields have similar ages of crustal formation and tectonic history, and were affected by at least three major tectono-thermal events: (1) the 3.5-2.9 Ga Leonean Orogeny (Morel, 1979); (2) the 2.9-2.8 Ga Liberian Orogeny (Egal et al., 2002) and (3) the 2.15-1.8 Ga Eburnean Orogeny (Feybesse et al., 2006; Markwitz et al., 2015)). The northern Precambrian shield area covers parts of Mauritania, Western Sahara/Morocco and Algeria with only two gold mines in Western Mauritania.

In the southern part of the West African Craton, the Archaean Kénéma-Man domain stretches across Sierra Leone and Liberia as well as parts of Guinea and Cote d'Ivoire, whereas Palaeoproterozoic rocks encompass a vast area of some $350,000 \mathrm{~km}^{2}$ covering parts of Guinea, Senegal, Mali, Benin, Togo, Ghana and most of Cote d'Ivoire and Burkina Faso (Figure 1). The latter Palaeoproterozoic terrain 


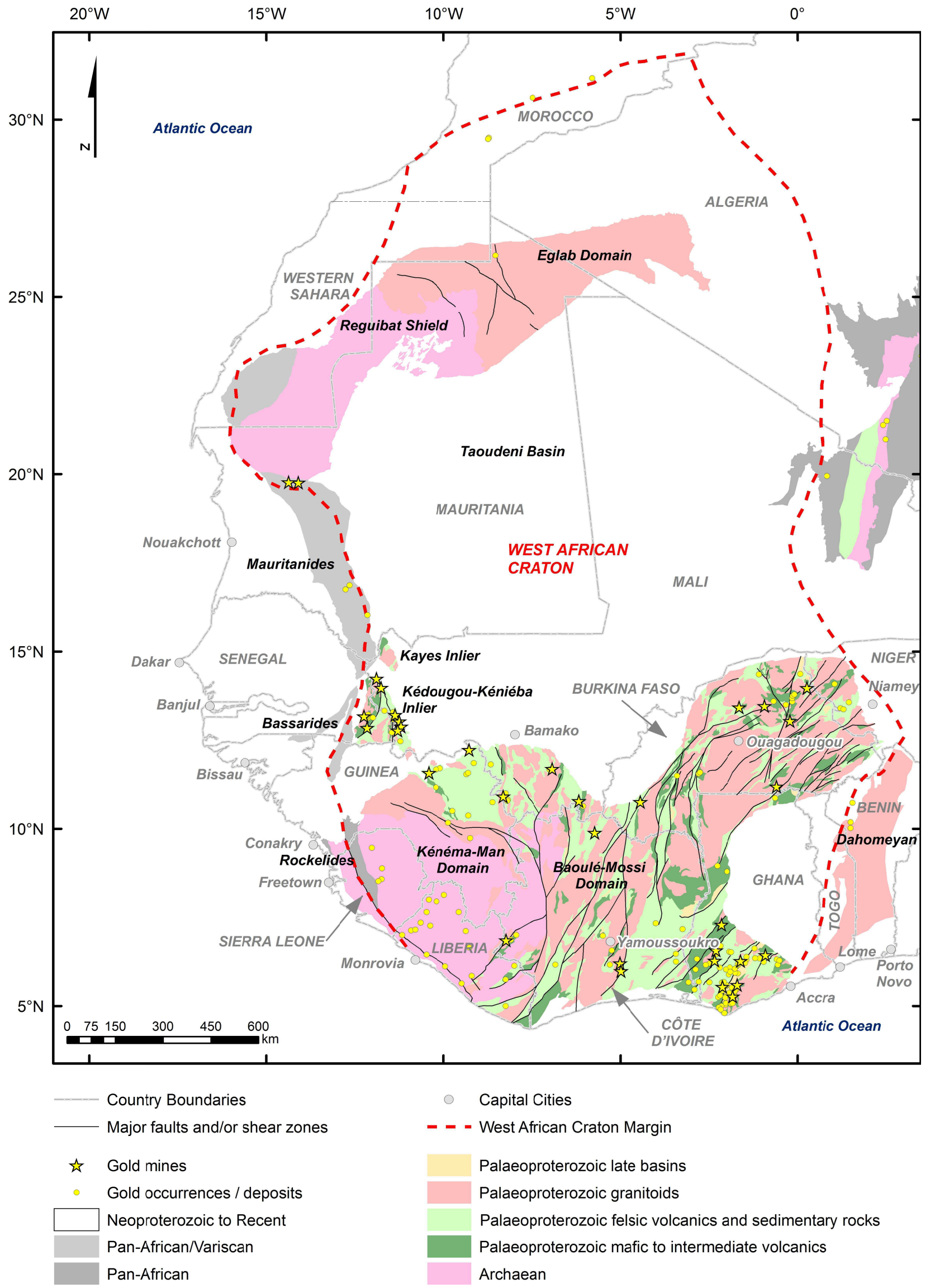

Figure 1. Generalised geological and structural map of the West African Craton showing the distribution of gold mines, deposits and occurrences (Source: Compiled from Jessell et al., 2012, Jessell and Liégeois, 2015, Lawrence et al., 2013a and Hammerbeck et al., 2008). 
consists of the Baoulé-Mossi domain and the Kédougou-Kéniéba, Kayes and Ansongo inliers, which are composed of volcanosedimentary sequences that underwent reworking during the Eburnean Orogeny (Figure 1).

The two Precambrian shield areas of West Africa are bounded by Pan-African (660-550 Ma) and Variscan ( 330 Ma) orogenic belts, namely the Rockelides, Bassarides and Mauritanides in the west and the Dahomeyan and Pharusian belts in the east (Figure 1) (Ennih and Liégeois, 2008a). The two shield areas are separated by the extensive intracratonic Neoproterozoic to Palaeozoic Taoudeni basin. The Volta, Bové and Tindouf basins were deposited during the same time period.

\section{Stratigraphy and Geological Setting}

The Archaean Kénéma-Man domain is a typical granite-greenstone terrain consisting of layered tonalite-trondhjemite-granodiorite (TTG) gneiss and supracrustal rocks containing greenstone sequences. The margins of the greenstone sequences were intruded by $2.73-2.78 \mathrm{Ga}$ granites, and ultramafic to mafic igneous intrusions (Kouamelan et al., 1997; Barth, et al., 2002).

The Palaeoproterozoic terrain, dominated by the Baoulé-Mossi domain, is composed of metamorphosed volcanic, volcanosedimentary and sedimentary rocks of the Birimian Supergroup (the "Birimian"), formed between 2.25 and 1.98 Ga (Feybesse et al., 2006). The Birimian is named after the Birim River in Ghana, where the rocks were first described by Kitson (1918). The Birimian is characterised by an alternation of "sedimentary basins" and "volcanic belts", intruded by Eburnean-age granitoids showing polyphase emplacement (Figure 1). The granitoids comprise approximately $70 \%$ of the Birimian terrane and form typically ovoid intrusions or composite batholiths that range in composition from TTGs to leucogranites (Hirdes et al., 1992). The "volcanic belts" comprise bimodal tholeiitic to calc-alkaline volcanics (Baratoux et al., 2011) and form linear greenstone belts which are generally northeast trending and which can extend over hundreds of kilometres.

The Birimian was originally subdivided into a lower volcanosedimentary sequence (Lower Birimian) and an upper metavolcanic sequence (Upper Birimian). However, problems with regards to correlating the sequence across West Africa (e.g. Griffis et al., 2002), together with geochronological work, led to reinterpretation by several workers and a revised understanding of the Upper and Lower Birimian as being coeval sequences (Eisenlohr and Hirdes, 1992), with the volcano-sedimentary sequence (Lower Birimian), being considered a distal facies of the metavolcanic belt (Upper Birimian) (Oberthür $e t$ al., 1997; Griffis et al., 2002).

Recent work by the WAXI, describes deposition of the dominantly volcanic, volcano-sedimentary and pyroclastite sequences of the lower Birimian in an oceanic arc to back-arc setting, in contrast to the dominantly volcano-sedimentary to sedimentary sequences of the upper Birimian which were deposited during a period of arc accretion synchronous with the Eburnean Orogeny (WAXI, 2013).

Birimian rocks are also preserved in the Kédougou Kéniéba and Kayes Inliers to the northwest of the Baoulé-Mossi domain, as well as in the small Ansongo (Kayes) Inlier to the northeast. The Kédougou Kéniéba Inlier covers an area of approximately $16,000 \mathrm{~km}^{2}$ straddling the Senegal-Mali border, and represents a window of Palaeoproterozoic Birimian rocks (Figure 2). The inlier represents the westernmost exposure of the Birimian and comprises two north- to north-northeast trending greenstone belts, known as the Mako Series and Falémé Series, and adjacent sedimentary basins referred to as the Dialé-Daléma Series and Kofi Series (Hirdes and Davis, 2002). The inlier differs from other Palaeoproterozoic terranes in the region by having an abundance of carbonates, with thick sequences (>250 m) in both the Dialé-Daléma Series and Kofi Series, representing the most extensive carbonate exposures in the Birimian of West Africa (Masurel et al., 2016). These domains are separated by terranebounding structures known as the Main Transcurrent Zone (MTZ) and Senegal-Mali Shear Zone (SMSZ) (Diene et al., 2015). The belts have been intruded by calc-alkaline granitoids, ranging from small plutons to large batholiths, typically more abundant in the west. The inlier is unconformably overlain by Neoproterozoic and Cambrian sedimentary cover rocks of the Taoudeni basin in the east (Figure 3) (Villeneuve and Cornée, 1994) and is bounded on its western margin by the Hercynian Mauritanide orogenic belt (Villeneuve, 2008) (Figure 1).

The dominant northeast-trending structural grain in the region was formed during the Eburnean Orogeny when the Birimian was metamorphosed to lower greenschist to amphibolite facies. Eburnean deformation was polyphase in nature, as noted by many workers, and is divided into two main events, namely the $\mathrm{D}_{1}$ Eoeburnean Event (also referred to as Tangaean or Eburnean-I) dated between 2.21$2.15 \mathrm{Ga}$, and the $\mathrm{D}_{2}$ Eburnean II Event dated between 2.13-2.05 Ga (Allibone et al., 2002; Feybesse et al., 2006; Hein, 2010; Baratoux et al., 2011; de Kock et al., 2011; Metelka et al., 2011; Perrouty et al., 2012; Jessell et al., 2012). The initial Eburnean I event corresponds to a major phase of crustal thickening as a result of shortening, folding and granitoid emplacement followed by Eburnean II regional-scale north to northeast-trending transcurrent faulting. These faults affected all lithologies and are often localised at contacts between granites and greenstones (Baratoux et al., 2011). In Mali, a third stage of deformation $\left(\mathrm{D}_{3}\right)$ is associated with transtensional movement along the $\mathrm{D}_{2}$ structures and the development of sinistral north- and northwest-trending Riedel shears (Diene et al., 2015).

Much of the gold mineralisation in the Biriman is concentrated along late orogenic shear zones related to the $\mathrm{D}_{2}$ and $\mathrm{D}_{3}$ deformation.

\section{Mines and Geological Models for Mineralisation}

Mineral deposits and occurrences in West Africa are documented in the West African Mineral Deposit Database (WAMDD). This database was produced between 2010 and 2013 by compiling available geological and resource data for the West African Craton and includes 441 mineral deposits and occurrences (Markwitz et al., 2015). A total of 198 gold deposits are included in the updated WAMDD.

Previous reviews around the geology of gold deposits in the West African region include those of Milési et al. (1992), Foster and Piper (1993), and Béziat et al. (2008). The most gold-endowed regions are spatially associated with the Baoulé-Mossi domain, the Archaean Kénéma-Man domain and the Kédougou-Kéniéba inlier, in the southwestern part of the West African Craton (Figure 1).

As a result of the intense exploration focus in the West African region over the past two decades, various gold deposit types have been recognised, namely orogenic, intrusion-related, skarn-hosted, porphyry-hosted, palaeoplacer and gold contained within iron oxidecopper-gold (IOCG) deposits (Markwitz et al., 2015). Supergene or 


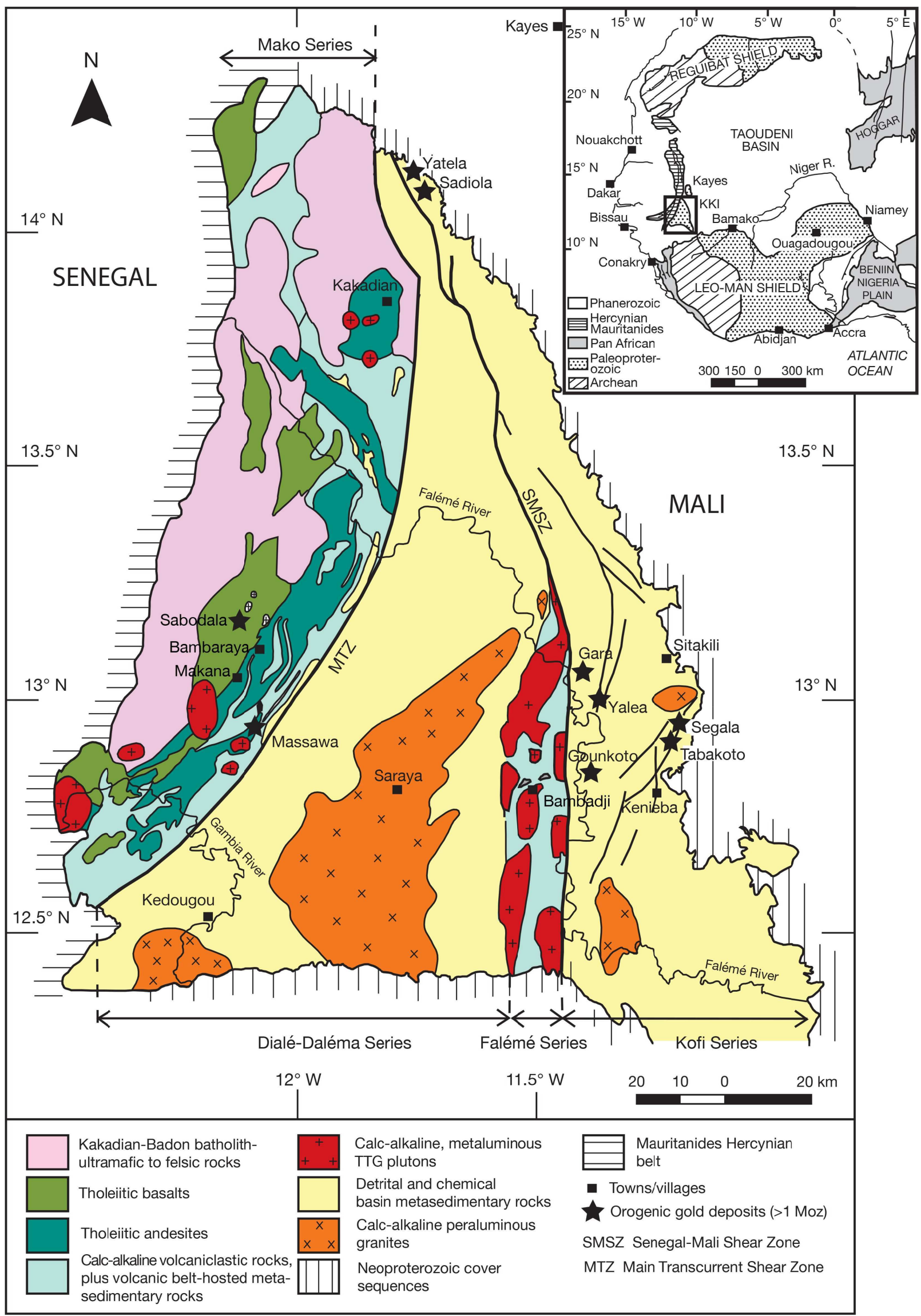

Figure 2. Geological map of the Kédougou Kéniéba inlier, showing the location of the major orogenic gold deposits (Source: modified after Lawrence et al., 2013a). 


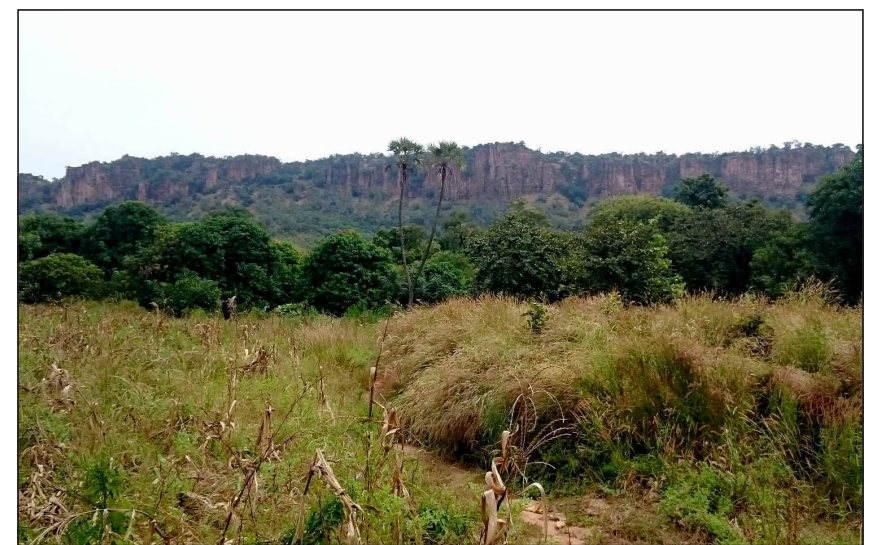

Figure 3. Neoproterozoic sedimentary cover on the eastern margin of the Kédougou Kéniéba inlier.

oxidised gold deposits are also known in the region, e.g. Yatela and Siguiri. This range in gold deposit types has expanded the opportunities for discovery in the region. The distribution of gold deposits is shown in Figure 1 and 4, with examples of different styles given below:

- Shear Zone-Hosted Vein: Ashanti (Obuasi), Prestea, Poura, Belahouro

- Disseminated, Shear-Zone Hosted: Bogosu, Konongo

- Breccia Disseminated: Syama, Sabodala

- Intrusive Disseminated: Ayenfuri

- Porphyry copper-gold: Diénémera

- Tourmalinite: Loulo

- Intrusive Contact: Ity, Morila, Sadiola

- Stockwork: Bouda, Guibare, Essakane, Djambaye II in the Tabakoto camp

- Extension Vein Stockwork: Kalana

- Skarn: Ity

- Palaeoplacer: Tarkwa

Notwithstanding the variation in deposit types listed above, two main types of mesothermal gold mineralisation occur within the Birimian, namely quartz vein-hosted and disseminated sulphide types, with most having developed during the Eburnean Orogeny between 2.2 and $1.8 \mathrm{Ga}$ (Béziat et al., 2008; Leube et al., 1990). There are also examples of atypical supergene deposits such as Yatela, which has been correlated with a glacial formation on the West African Craton formed during the Miocene-Eocene epochs (Matsheka and Hein, 2011). Gold mineralisation in the Archaean of Sierra Leone and Liberia dates to $2.9 \mathrm{Ga}$ (Foster and Piper, 1993).

The majority of gold deposits on the West African Craton are orogenic-style deposits and can be generally described as gold-bearing quartz veins, stringers and wall rock replacement, accompanied by minor sulphides and localised by brittle to ductile structures within various host rock types. The majority of deposits occur within rocks that have been metamorphosed to greenschist facies, within a metamorphic pressure-temperature regime broadly corresponding to the brittle-ductile transition.

Although a large number of such deposits share broad similarities, the nature of the gold distribution is highly variable at a local scale and between deposits. Mineralisation is typically associated with swarms of discontinuous veins of varying thickness and extent and as disseminations in sheared and altered wall rock. Gold occurs as native gold and/or associated with sulphides, with pyrite and arsenopyrite being the most commonly reported. Other metals such as copper and nickel can occur in economic quantities.

Common criteria to all styles include a structural framework, receptive host rocks with strong competency/rheological contrasts and evidence of polyphase intrusives, deformation and alteration events.

Skarn deposits can form where granitic bodies intrude a carbonatebearing metasedimentary sequence, e.g. the Ity deposits in Côte d'Ivoire in which sulphur-rich skarns (3-10\% pyrite-pyrrhotitechalcopyrite), with accessory magnetite are present. These deposits can lend themselves to efficient heap leaching where they are oxidised in the near-surface environment and the carbonate is dissolved.

The locations of the main gold mines in the West African region are shown in Figure 4. The range in style of mineralisation and local geological setting is described below by way of examples from operating mines in Mali, Senegal, Côte d'Ivoire, Burkina Faso and Guinea. The Birimian gold deposits of Ghana are described in Smith et al. (this volume).

\section{The Archaean domains}

Gold mineralisation in the Archaean Kénéma-Man domain formed during the 2.9-2.8 Ga Liberian Orogeny, and is associated with quartz lodes in shear zones developed in poorly defined greenstone belts (Markwitz et al., 2015) (Figure 1). Basement granite-gneiss complexes and granulitic meta-gabbro gneiss are generally barren (Markwitz et al., 2015), except where the mineralisation is focussed along lithological contacts between granites, migmatitic gneiss, ultramafics and amphibolite. A strong association exists between mineralised gold zones and secondary and higher order shears, faults and quartz lodes (Foster and Piper, 1993).

Orogenic gold mineralisation in the Sula Kangari and Nimini greenstone belts of central Sierra Leone is hosted in structurallycontrolled quartz-pyrite-arsenopyrite lodes in banded iron formations and amphibolites (Foster and Piper, 1993). Within this setting, gold is associated with thrust faults (Markwitz et al., 2015).

In the Lofa River region of western Liberia, the New Liberty gold mine $(1.7 \mathrm{Moz})$ is hosted in a series of west-northwest trending quartz lodes in an ultramafic body near the contact of leucocratic gneiss and amphibolite (Markwitz et al., 2015). A significant zone of gold mineralisation extends along the length of the Cestos Shear Zone in central eastern Liberia. The shear zone is considered the boundary between the Archaean and Palaeoproterozoic rocks in Liberia. The latter region is currently the focus of intense artisanal mining activities (Markwitz et al., 2015).

In contrast to the Archaean Kénéma-Man domain, the Archaean Reguibat Shield currently presents a limited gold endowment, apart from the 9.6 Moz Tasiast deposit, which is located in the $75 \mathrm{~km}$ long, north-south trending Aouéouat greenstone belt (Markwitz et al., 2015). The Tasiast gold mine is situated within a package of strongly folded and sheared rocks in the hangingwall of the approximately northsouth trending Tasiast thrust system (Sims, 2014), which is structurally controlled by late, discrete faults and shears (Stuart, 2010). The gold is hosted by a series of east-west trending quartz-carbonate veins that are folded and locally transposed.

\section{The Palaeoproterozoic Baoulé-Mossi domain}

The Baoulé-Mossi domain comprises the major part of the 


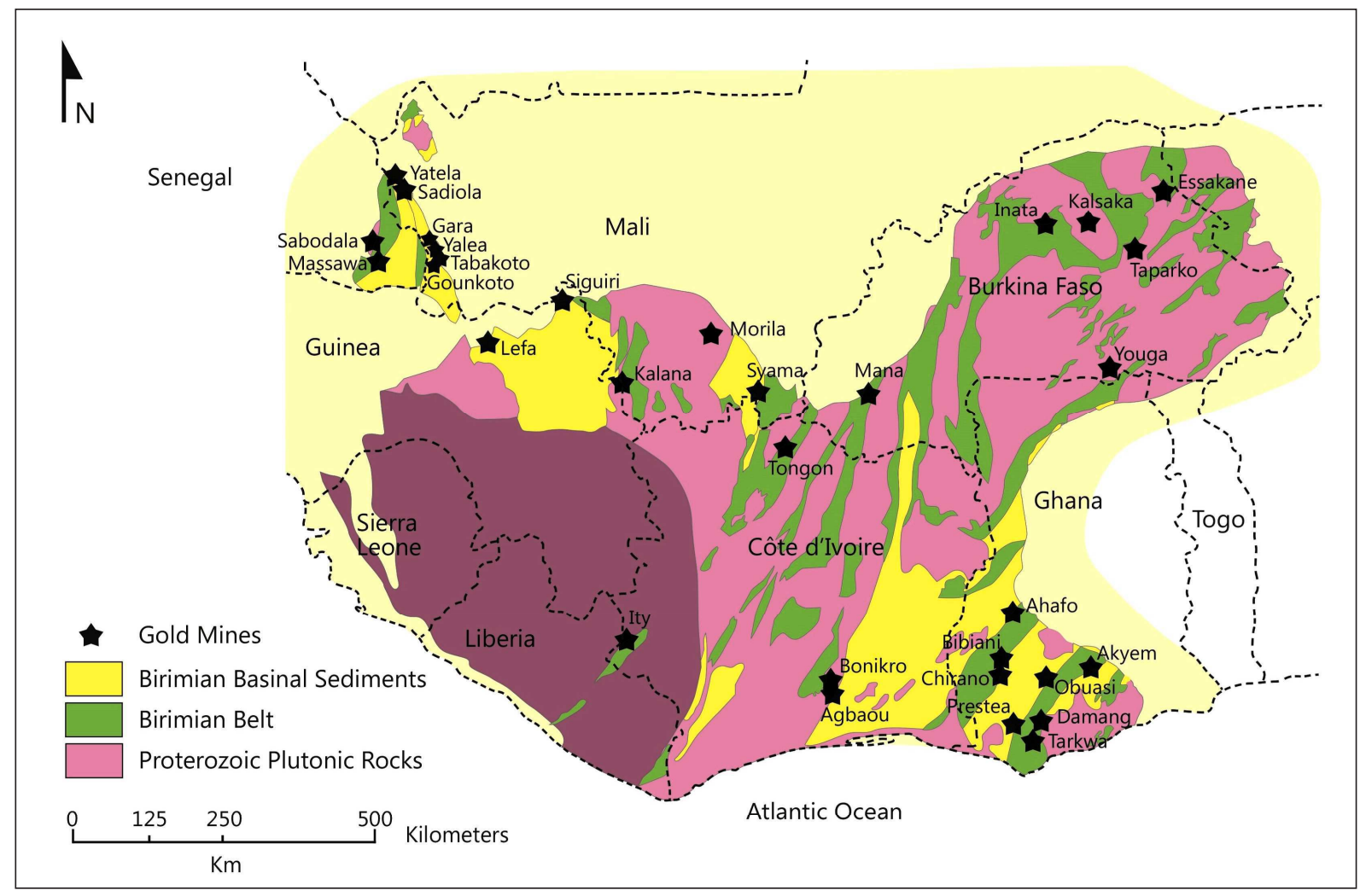

Figure 4. Location of the major gold mines in the West African region in relation to the simplified geology (Source: modified after Holliday, 2014).

Palaeoproterozoic Birimian, covering large extents of Mali, Côte d'Ivoire, Burkina Faso, Ghana and Guinea. This section describes examples of the geological setting and mineralisation of gold deposits in the Baoulé-Mossi domain, from selected mines across the region.

\section{Morila}

The Morila deposit is located in southern Mali, some $280 \mathrm{~km}$ southeast of Bamako (Figure 4). A summary of the Morila deposit is presented in McFarlane et al. (2011) and Hammond et al. (2011).

Morila was discovered during general prospecting, geological mapping and soil geochemical sampling of the Massigui region between December 1985 and June 1987. The gold-arsenic soil anomaly was initially tested by BHP from 1992 with auger drilling, ground geophysics and reconnaissance diamond drilling. Randgold Resources carried out trenching and further diamond drilling from 2006. The mine commenced production in 2000 and produced 6.2 Moz of gold between 2000 and 2012. Since 2009, the mine has been converted from an open pit to a stockpile treatment operation. Morila is owned by Randgold Resources (40\%), AngloGold Ashanti (40\%), and the Government of Mali (20\%).

The deposit is interpreted as a reduced intrusion-related gold system, overprinted by an orogenic gold event (McFarlane et al., 2011) and is located in the Massigui region of southern Mali, which is underlain by Birimian volcano-sedimentary rocks and granitic intrusives of the Bougouni terrane. The terrane lies between the Kalana-Yanfolila and Boundiali greenstone belts; the latter hosting the Syama gold deposit $\sim 100 \mathrm{~km}$ to the southeast of Morila (Olson et al., 1992) (Figure 4).
Morila is hosted in a package of strongly folded meta-greywackes (biotite schists), and minor meta-volcanic (meta-basalt) and metavolcaniclastic rocks which are intruded by large granitoid batholiths and smaller intrusive stocks.

At least two main stages of hydrothermal alteration are associated with mineralisation at Morila (Hammond et al., 2011; McFarlane et al., 2011). The geometry of the orebody contrasts with the steeply dipping, tabular morphology typical of shear-hosted orogenic gold deposits, in that the orebody is flat lying to gently dipping to the east and varies in thickness from 25 to 160 metres (Figure 5) (McFarlane et al., 2011). The thickness also increases to the south and west, close to the contact with the Morila Tonalite. The orebody is effectively strata bound and confined to a biotite schist unit.

Two stages of folding are observed (McFarlane et al., 2011) with high grade gold mineralisation (average grades $>10 \mathrm{~g} / \mathrm{t}$ ) concentrated along the hinge of a fold, known locally as the Morila Antiform.

Two main stages of gold mineralisation have been characterized at Morila (McFarlane et al., 2011). An initial phase is spatially and genetically associated with syn- to post- $\mathrm{D}_{2}$ tonalites and leucogranites, and is interpreted by McFarlane et al. (2011) to represent a reduced intrusion-related gold event. Mineralisation is associated with millimetre to centimetre-scale polymineralic quartz-rich veins, with varying concentrations of hornblende, biotite, plagioclase and fluorapatite. Sulphide assemblages consist of löllingite, pyrrhotite and chalcopyrite. Visible native gold is associated with scheelite, native bismuth, maldonite $\left(\mathrm{Au}_{2} \mathrm{Bi}\right)$, aurostibite $\left(\mathrm{AuSb}_{2}\right)$ and tellurobismuthite $\left(\mathrm{Bi}_{2} \mathrm{Te}_{3}\right)$.

A second overprinting phase of gold mineralisation is associated with albitization and disseminated arsenopyrite growth. Arsenopyrite hosts the bulk of the gold mineralisation at Morilia. Gold inclusions 


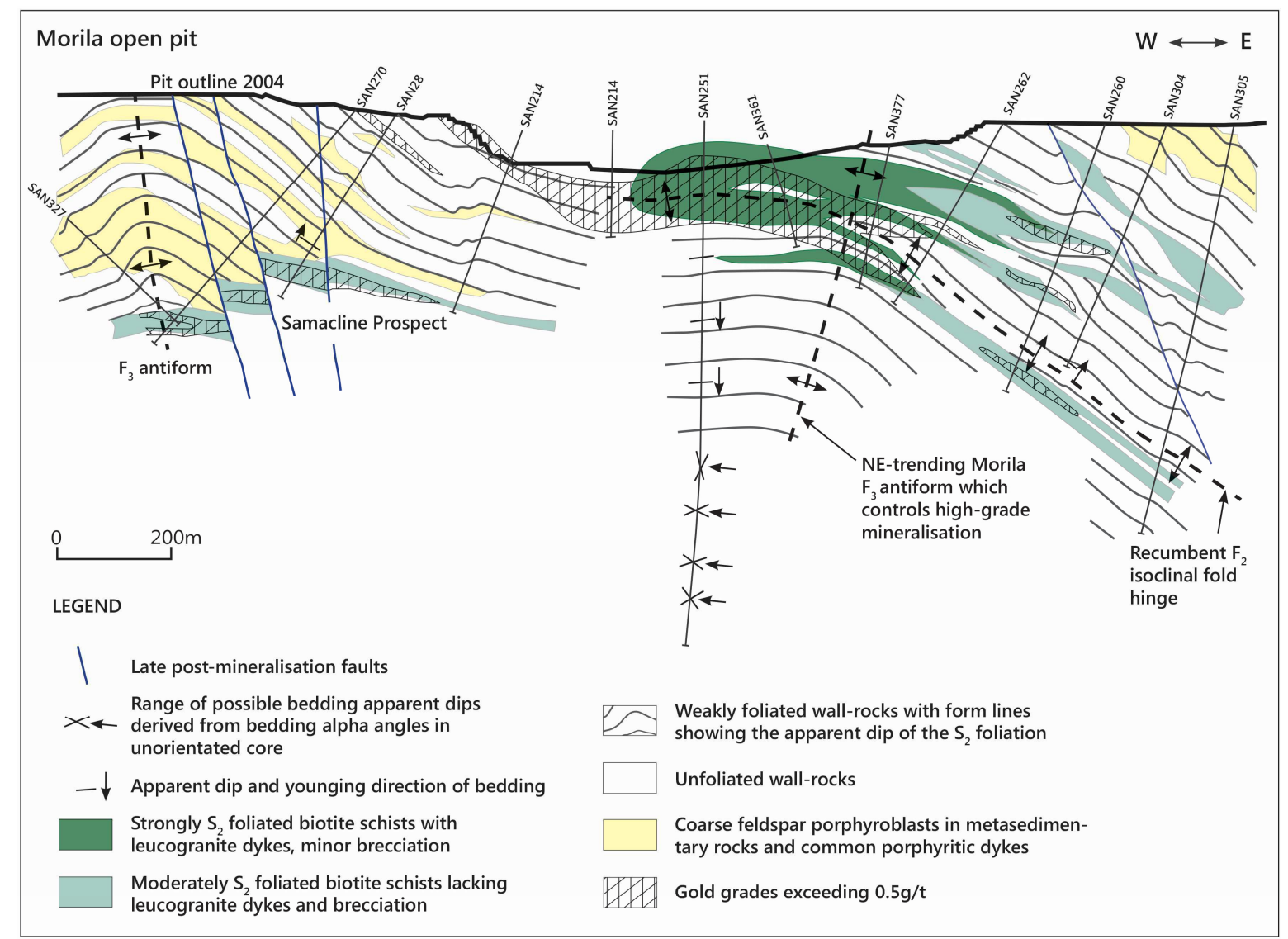

Figure 5. Section through the central part of the Morila deposit showing the geometry of the orebody and the multi-phase development of folding (Source: McFarlane et al., 2011).

are from 5 to $25 \mu \mathrm{m}$ in diameter, are typically polygonal in shape, and are largely concentrated near arsenopyrite cores. McFarlane et al. (2011) proposed an orogenic gold related origin for this mineralisation event.

\section{Syama}

The Syama gold mine is located in southern Mali, approximately $300 \mathrm{~km}$ southeast of Bamako and $30 \mathrm{~km}$ from the Côte d'Ivoire border (Figure 4). Resolute Mining Limited has an $80 \%$ interest in the project with the Malian Government holding a 20\% interest.

The history and geology of the Syama deposit is described in Olson et al. (1992). Ancient mining dating to around $1200 \mathrm{AD}$ is recorded at Syama, when gold was extracted from extensive shallow workings in the oxide zone (Sanogo, et al., 1987). The placer potential of the area was investigated by the BRGM and Société Nationale de Recherche Minère of Mali during the 1960s and 1970s. An oxide resource of $1.5 \mathrm{Mt}$ at $1.67 \mathrm{~g} / \mathrm{t} \mathrm{Au}$ was outlined following regional soil sampling and pitting by the UNDP. An extensive drilling programme was carried out by BHP-Utah Minerals from 1987 to 1990, which identified extensive sulphide mineralisation below the oxide workings. Production from oxide ore at the Syama open pit commenced in January 1990.

Syama produced 165,493 ounces of gold in 2014 at an overall head grade of $3.73 \mathrm{~g} / \mathrm{t} \mathrm{Au}$. Mining to date has been from the Syama open pit, with mining of oxide ore due to commence from the new A21 pit north of the Syama main pit. A prefeasibility study on an underground mine has been completed.
Gold mineralisation at Syama lies within a major reverse fault zone on the margin of a narrow ( 0.5 to $2 \mathrm{~km}$ wide), but regionally extensive greenstone belt sequence of basalt and andesite, with interbedded greywacke and argillite, bounded to the east and west by Birimian greywackes and argillites. The reverse faults coincide with abrupt regional- and mine-scale contrasts in rock competency. Intrusive rocks comprise a volumetrically significant component of the host sequence and may have aided hydrothermal alteration.

In the Syama area this ore-bearing sequence is structurally layered, overturned and east vergent. Massive competent basalt and conglomerate bound the hangingwall and footwall of the mineralised interval respectively (Olson, et al., 1992).

The oxide mineralised zone is developed to a depth of 35 to 40 metres and was expressed on the surface by sparse outcrops of silicified rocks and as a series of 3 to 15 metre deep ancient mine workings, which extended 800 metres along the strike of the deposit. In 1990, the estimated mineable reserves of oxide material were $3 \mathrm{Mt}$ at an average grade of $3.2 \mathrm{~g} / \mathrm{t}$ Au with sulphide reserves of $21 \mathrm{Mt}$ at an average grade of $4.02 \mathrm{~g} / \mathrm{t}$ Au to a depth of 320 metres below surface.

The sulphide zone comprises lenticular bodies of intense ankeritequartz veinlet stockworks, zones of sheeted ankerite-quartz veinlets and breccia bodies. Pyrite is the principal gold-bearing mineral and occurs disseminated in veinlet haloes and breccia clasts. Gold occurs as sub-micron to visible inclusions in and around the edges of pyrite crystals and as free gold. Pyritic quartz-ankerite veining is largely restricted to high pyrite (7 to $10 \%$ ) zones. Breccias and intense stockwork zones host most of the higher grade $(>4 \mathrm{~g} / \mathrm{t} \mathrm{Au})$ 
mineralisation. Sheeted veins are spaced at a density of more than five per metre and are 1 to $10 \mathrm{~mm}$ thick.

Green chloritic basalt is the preferred, but not the exclusive, host of the mineralisation. The basalt is commonly bleached by ankerite, albite and sericite alteration in the pyritic gold bearing zones. Andesitic-lamprophyric intrusives and greywacke-argillite layers also host mineralisation. Within the intrusives, low grade ore occurs as weak stockworks of quartz-ankerite veins, while the sediments mainly host disseminated sulphides and fine quartz-ankerite stockworks. Faulted beds of graphitic greywacke-argillite and zones of silicification bound most individual ore lenses (Olson, et al., 1992).

\section{Tongon}

The Tongon gold mine is located in northern Côte d'Ivoire (Figure 4) and is owned by Randgold Resources (89\%) the Government of Côte d'Ivoire (10\%) and a local company (1\%). The Tongon deposit is described in Lawrence (2013).

Modern exploration activities began in 1988 when a joint venture between BHP and Societé pour le Developpement Minier de la Côte d'Ivoire (SODEMI), conducted extensive regional exploration over large areas of northern Côte d'Ivoire. This work included regional and detailed soil sampling, pitting, trenching and auger drilling. Five targets were then subjected to reconnaissance reverse circulation and diamond drilling, with the most significant mineralisation being discovered at Tongon.

Randgold Resources initiated field exploration activities in early 1997 and carried out further work until June 2002, when exploration ceased during the Ivorian Civil War. The Tongon mine was officially opened in 2010. The mine comprises two open pit operations, namely the Southern and Northern zones. A total of 227,103 ounces of gold were produced in 2014.

The Tongon mine is located within the north-northeasterly to northeasterly trending Birimian Senoufo greenstone belt, which extends from Kani in the south, northward into Burkina Faso for a distance of greater than $200 \mathrm{~km}$. Basement granitoid-gneiss terranes flank the belt to the west and east. The belt lies approximately $80 \mathrm{~km}$ to the east of the Boundiali greenstone belt, which hosts the Syama gold deposit in southern Mali (Olson et al., 1992).

The Senoufo belt comprises a western basaltic sequence, a central andesitic volcanic-volcaniclastic package, and an eastern back-arc basin infill sequence of meta-sedimentary units consisting of finegrained siliciclastic rocks including shales, carbonaceous shales, greywackes and quartz-mica schists. Felsic-intermediate calc-alkaline plutons, of various generations and sizes, intrude the volcanicsedimentary packages.

Gold mineralisation occurs in two zones, namely Tongon North and Tongon South. Both zones are characterized by a sequence of volcaniclastic rocks, ranging from coarse grained polymictic breccias, to fine grained tuffs intercalated with carbonaceous sedimentary units. Immediately to the west of the orebodies, a granodiorite-diorite pluton intrudes the volcaniclastic sequence and appears to postdate mineralisation. Late porphyritic and gabbroic dykes are seen crosscutting all lithologies.

The Senoufo belt is largely controlled by a series of northnortheasterly to northeasterly striking thrust faults. A $3 \mathrm{~km}$ wide zone of east-northeast striking transfer faults cut across the Senoufo belt in the vicinity of Tongon. These transfer faults link thrust faults to the north and south. The Tongon orebodies themselves are located in and adjacent to a kilometre-scale jog in one of these transfer faults. A post-mineralisation granodiorite-diorite pluton on the immediate northwestern side of Tongon was also emplaced in this jog.

An earlier phase of intense calc-silicate alteration was followed by a silica-ankerite \pm biotite \pm chlorite \pm prehnite alteration event coincident with sulphide and gold mineralisation. The Tongon South orebody is characterized by multiple, structurally-controlled, north to northeasterly trending, shallow to moderately northwest dipping lodes, which extend for approximately $1.5 \mathrm{~km}$ along strike, and which may represent a thrust duplex. The shears appear to terminate along the contact with the diorite pluton. These structures control both main stages of hydrothermal alteration as well as gold mineralisation. Individual lodes mainly vary in thickness from less than 5 to $20 \mathrm{~m}$.

At Tongon North, mineralisation is confined to one steeply northwesterly dipping $\left(\sim 70^{\circ} \mathrm{dip}\right)$ lode, along a strike length of $2.2 \mathrm{~km}$. The mineralised zone varies in thickness from 3 to $35 \mathrm{~m}$, and is located between two carbonaceous shale units which act as the hangingwall and footwall.

Mineralisation at both deposits consists of disseminated pyrrhotite, pyrite, arsenopyrite, löllingite and minor chalcopyrite. High-grade zones at Tongon South are associated with elevated tungsten (W) concentrations in the form of scheelite. The majority of the gold at Tongon is associated with arsenopyrite as small inclusions (generally $<10 \mu \mathrm{m})$ and rarer colloidal and lattice bound gold. Silver contents of native gold grains average approximately $10 \mathrm{wt} \%$.

\section{Agbaou}

The Agbaou Gold Mine is located approximately $200 \mathrm{~km}$ north of the port city of Abidjan in Côte d'Ivoire (Figure 4). The mine is owned by Endeavour Mining (85\%), while the Government of Côte d'Ivoire and the Société pour le Dévelopment Minier de la Côte d'Ivoire (SODEMI - the State owned mining company) hold a $10 \%$ and a $5 \%$ free carried interest respectively. The history, geology and mineralisation of the Agbaou deposit is described in Roux et al. (2015).

Alluvial gold has been known and exploited by local gold panners ("orpailleurs") for some time in the Agbaou area. Gold mineralisation in bedrock was first reported during the late 1980s and was followed by extensive exploration conducted by several companies from 1988.

Commercial production was achieved in January 2014 and mining is carried out using conventional open pit methods. In 2014, Agbaou produced 146,757 ounces of gold (Endeavour Mining website, 2015).

The Agbaou deposit is located within the Birmian-age OuméFetekro Greenstone Belt, which consists of a volcano-sedimentary succession developed along a northeast trending shear zone (Figure 6). The belt is surrounded by granodioritic intrusions. Gold mineralisation is located on multiple sub-vertical, parallel structures within north-northwest trending faults and secondary structures dipping between 50 and 80 degrees to the southeast. Gold occurs in a pyrite-pyrrhotite assemblage associated with quartz veining. The quartz veins are characterized by a wide range of vein types, brecciation, boudinage, sericitic and carbonate alteration; however, the mineralised quartz veins have a very distinctive texture that has been described as "mottled" (Roux, et al., 2015).

Significant exploration potential exists along strike of the known structures. 


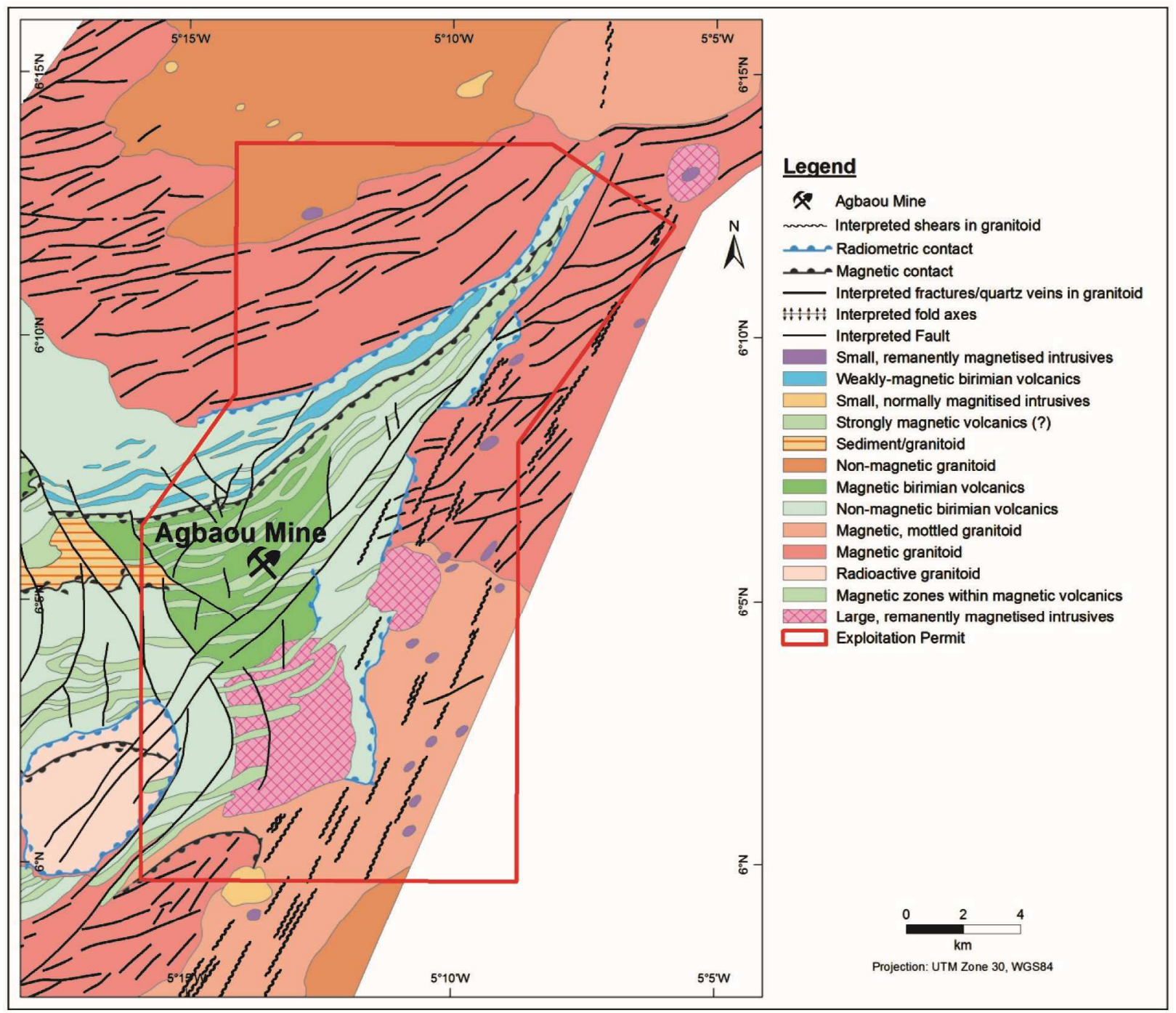

Figure 6. Geological and structural map of the Agbaou permit area (Source: Roux et al., 2015).

Ity

The Ity gold mine is located in southwestern Côte d'Ivoire, $480 \mathrm{~km}$ northwest of Abidjan (Figure 4). Ity has the longest operating history of any modern gold mine in the country (Béziat et al., 2015). Endeavour Mining holds a 55\% interest in the Ity Gold Mine while the remainder is held $30 \%$ by SODEMI, $10 \%$ by the Government of Côte d'Ivoire, and $5 \%$ by a private investor.

Production at the Ity mine commenced in 1991 as an open pit and heap leach operation. To date, over $1 \mathrm{Moz}$ of gold have been produced from multiple deposits, with 82,000 ounces produced in 2014 (www.endeavourmining.com). Following a positive prefeasibility study to evaluate the potential of a carbon-in-leach (CIL) plant, drilling programmes have been carried out to upgrade the mineral resource status of the various deposits.

The geology and mineralisation at the Ity mine are described in Body et al. (2015) and Béziat et al. (2015). Copper and gold were first discovered near the village of Ity in the 1950s during regional exploration by the Bureau Minière de la France d'Outre-Mer. Prior to 1991, attempts to recover the gold were unsuccessful due to the fineness of the gold and the competency of the ore.

The Ity deposits are located in Birimian rocks of the Toulépleu-
Ity klippe, a small outlier of Birimian within the Archaean portion of the West African Craton. The Ity region is characterised by a series of granodioritic intrusions into a metasedimentary sequence of volcanosediments and carbonates, with a general northeast-southwest strike. The volcanic deposits are tuffaceous with a composition ranging from basic to acidic. All formations have been subjected to greenschist facies regional metamorphism.

The deposits of Mont Ity, Zia NE and Flotouo, are skarns developed at the contact of the granodiorite with carbonates (Figure 7). Primary mineralisation within the skarns occurs in the form of stockworks and is dominated by pyrite, with subordinate arsenopyrite, sphalerite, galena and sulphosalts. The skarns have undergone oxidation and dissolution of sulphides and carbonate, which has resulted in the generation of karsts into which saprolitic material collapsed (Figure 7). The exploited gold mineralisation at Ity is hosted in the saprolite zone (50-120 m thick) and consists of several mineralised lenses of clayey and ferruginous material ("terres noires") and sedimentary breccia layers. A thick laterite horizon (minimum $10 \mathrm{~m}$ thick) overlies the saprolite, and also hosts supergene gold mineralisation.

Other gold deposits in the area are more typical of orogenic type deposits. 


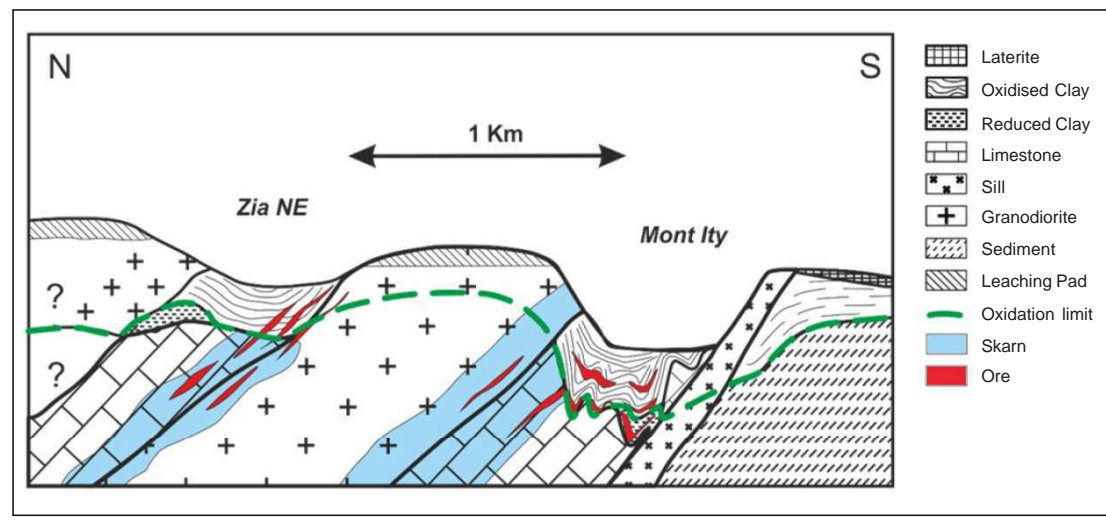

Figure 7. Schematic geological section of the Ity deposits (Source: Body et al., 2015).

Currently, Essakane is $90 \%$ owned by IAMGOLD, with the remaining $10 \%$ owned by the Government of Burkina Faso.

The Essakane Project is located in the Palaeoproterozoic Oudalan-Gorouol greenstone belt (OGGB) in northern Burkina Faso. It is hosted within the lower meta-sedimentary sequence and associated with the Markoye Shear Zone (MSZ). The MSZ is a regional, northeasterly trending first-order structure that transects the entire belt. The OGGB has undergone at least two deformation events, namely the Tangaean Event and Eburnean Orogeny (Tshibubudze et al., 2009).

The geology and gold mineralisation at Essakane are described in Tshibubudze and Hein (2015).

\section{Essakane}

The Essakane gold mine is located in north-eastern Burkina Faso (Figure 4), where it straddles the boundary of the Oudalan and Seno provinces in the Sahel region. The project is situated $330 \mathrm{~km}$ northeast of the capital, Ouagadougou and $42 \mathrm{~km}$ east of the town of GoromGorom, the capital of Oudalan province.

Essakane was discovered by artisanal miners in 1985. The Bureau des Mines et de la Géologie du Burkina (BUMIGEB), undertook regional mapping and geochemical programmes between 1989 and 1991, and later arranged and financed a programme of heap leach test work. The Compagnie d'Exploitation des Mines d'Or du Burkina (CEMOB) acquired a mining permit over the site in 1991.

Several companies were involved in the project until 2002 when Orezone Resources and Gold Fields undertook a joint venture on the project. The Gold Fields stake was later bought out by Orezone Resources in 2007. IAMGOLD acquired Orezone Resources in February 2009 and began production at Essakane in July 2010.
Essakane is classified as an orogenic gold deposit. The deposit is hosted within a vertical, asymmetric anticline which plunges shallowly to the northwest (Figure 8). The highest concentration of gold mineralisation and quartz veins occur within a $\sim 60$ metre thick 'main arenite unit'. High gold concentrations are also found in the hinge zone and eastern fold limb of the anticline.

Two discrete structural controls on the gold mineralisation have been identified: (1) An association of gold with layer parallel deformation; and (2) gold mineralisation concentrated in structures that formed during folding. The deposit is developed over a strike length of 2,500 metres. Mineralisation follows the fold plunge and economic grades at increasing depths have been confirmed to 270 metres vertically below surface. The full depth extent of gold in the fold hinge and east limb has yet to be determined (IAMGOLD website).

The typical alteration assemblage in the mineralised arenite unit is characterised by sericite-carbonate-silica-albite. Arsenopyrite and pyrite occur within and adjacent to quartz veins. Arsenopyrite is

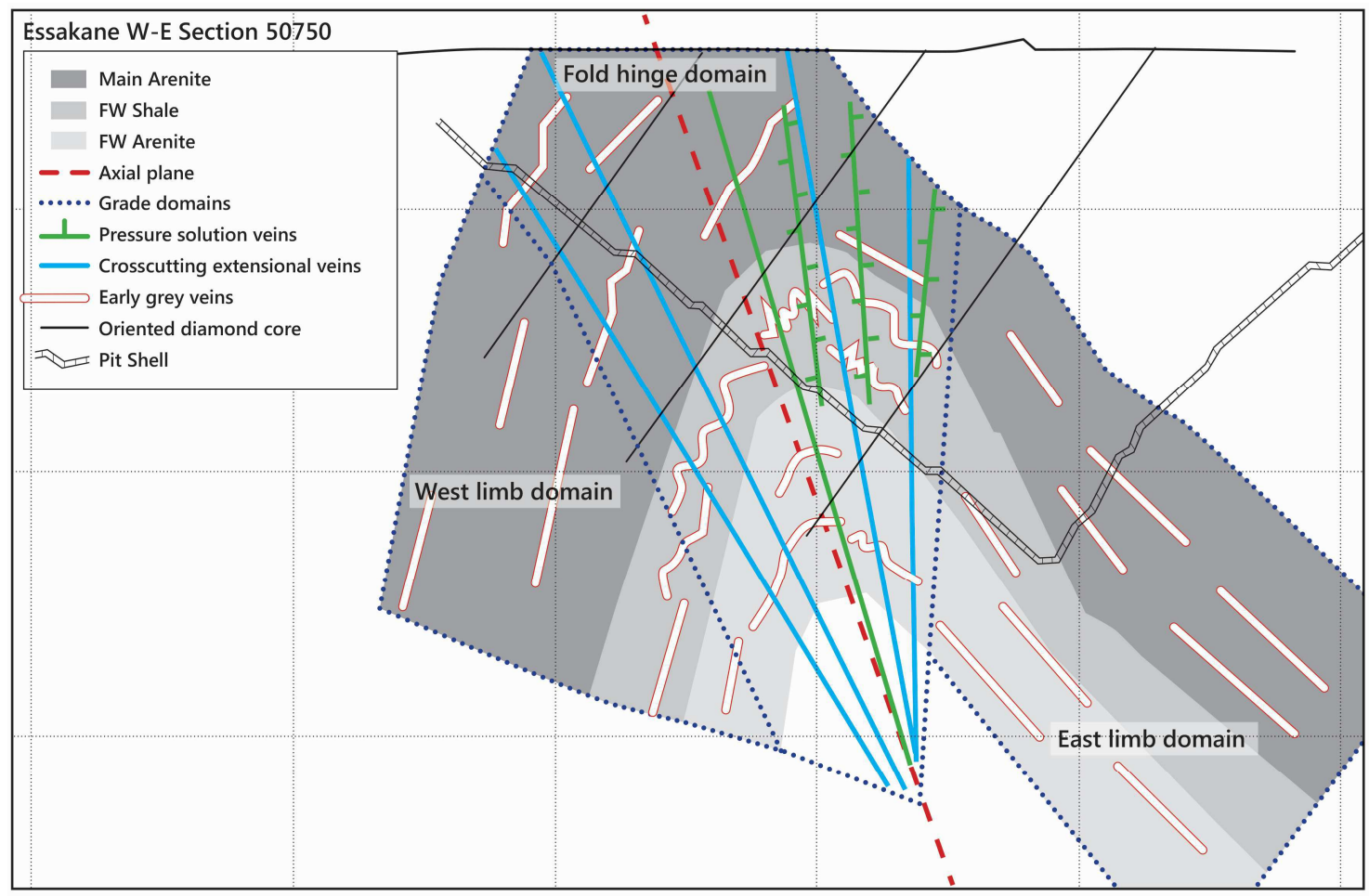

Figure 8. Cross section of the Essakane anticline showing the fold hinge, west limb and east limb domains (www.iamgold.com). 
occasionally associated with trace amounts of chalcopyrite, galena and hematite. The gold occurs in two different forms, either as free gold within the quartz veins, or as intergrowths within sulphides that occur adjacent to the veins.

Essakane was expected to reach full production capacity in 2015. Mining of the Falagountou deposit, southeast of Essakane, is also planned in order to optimise grades and sustain ideal throughput rates. Production in 2015 was anticipated to be between 360,000 and 370,000 ounces of gold (IAMGOLD webiste).

\section{Inata}

The Inata project forms part of the Bélahouro Gold Project, which is located in the north of Burkina Faso, approximately $220 \mathrm{~km}$ north of Ouagadougou (Figure 4). The Bélahouro district lies on the eastern edge of a Birimian greenstone belt.

BHP Billiton Ltd (BHP) originally held the Licence in 1999 and conducted an extensive mapping and sampling program, followed by trenching, reverse circulation and diamond drilling. In January 2000, Resolute Mining bought a majority share of $54 \%$ of Inata and by November 2000, took 100\% ownership of the project. In March 2005, ownership was transferred to Goldbelt Resources Ltd, and in July 2009, to Wega Mining ASA. Avocet Mining Plc. (Avocet), acquired Wega Mining in June 2009 and currently owns $90 \%$ of the project. The remaining $10 \%$ is owned by the Government of Burkina Faso. The mine was commissioned and production began in 2009 (www.avocet.com).

Three geological domains are recognised, namely the DambaInata Province, the Bélahouro Basin, and the Feto Kole Volcanic Province.

At Inata, mineralisation is located within a distinct shear zone that separates granitic and volcanic rocks of the Damba-Inata Province in the west, from the Sona Sedimentary Basin in the east. Gold mineralisation is hosted in a sub-vertical shear zone which transects folded carbonaceous shales. The shear zone is intruded by quartzfeldspar porphyry dykes that were emplaced concurrently with later stages of gold mineralisation. Disseminated gold occurs in hematitic alteration haloes, surrounding quartz-carbonate-albite veins. Gold is also hosted in boudinaged, folded and brecciated quartz veins. Inata is currently being mined by conventional open pit methods and comprises six open pits. The focus is on the North, Central and Far South pits (www.avocet.com).

The mining license covers an area of $26 \mathrm{~km}^{2}$ and potential exists to increase the mineral resource at Inata within this area, with recent drilling focussed on expanding the known mineralisation at Inata North, Minfo and Minfo East.

\section{Taparko}

The Taparko gold mine is located in the Namantenga Province of Burkina Faso, approximately $200 \mathrm{~km}$ northeast of Ouagadougou (Figure 4).

The mine is owned by Nordgold and operated by SOMITA SA, a company $90 \%$ owned by one of Nordgold's subsidiaries, High River Gold Mines Ltd, and $10 \%$ by the Government of Burkina Faso. Gold production in 2014 was $112,000 \mathrm{oz}$. The original discovery at Taparko was made in 1980 by the Burkina Faso Government Bureau of Mines and Geology. High River Gold Mines Ltd and Incanore Gold Mines Ltd. entered into a joint venture agreement for the Taparko property in August 1993. In 2002, High River Gold Mines Ltd acquired the entire project. Taparko was the first gold mine built in Burkina Faso with mining having commenced in 2005 and the first gold being poured in late 2007 (www.nordgold.com).

The Taparko goldfield is located in the Yalago greenstone belt, which comprises a variety of interbedded metasedimentary units and volcanic rocks, typically metabasalts and meta-andesites. Northeast trending, first-order shear zones transect the belt near the Taparko goldfields (Tshibubudze et al., 2009; Peters, 2013).

Gold mineralisation, in the Taparko area is related to a system of quartz veins and veinlets, hosted in a northwest trending shear zone ranging between 5 and 20 metres in width. The veins are typically northwest striking, and dip to the northeast at approximately 45 degrees. Three separate mineralised zones occur at Taparko, namely Zone 3/5 (1.10 km long), Zone 2N/2K (500 metres long) and Zone GT (400 metres long) (www.nordgold.com).

Potential exists at Taparko to increase the resource/reserve base and life of mine through the development of satellite targets such as Yeou, Goengo, Bissinga and Zemce (www.nordgold.com).

\section{Siguiri}

The Siguiri Mining Complex is owned by AngloGold Ashanti $(85 \%)$ and the Government of Guinea (15\%) and is located in northeastern Guinea, $25 \mathrm{~km}$ northwest of the town of Siguiri and 830 $\mathrm{km}$ northeast of the capital, Conakry (Figure 4). The region has long been an area of traditional artisanal gold mining.

The mining complex comprises nine current open pit oxide operations. Gold mineralisation is hosted within a low-grade metamorphic turbiditic succession within the Larger Siguiri Basin, which forms part of the Boualé-Mossi domain of the Birimian (Steyn, 2012). The deposits are characterised by a deeply (50 to $150 \mathrm{~m}$ ) weathered saprolite profile, developed over a monotonous succession of interbedded metapelites and metapsammites, which at depth, manifest as quartz-muscovite schists, muscovite-chlorite schists and metagreywackes.

The structural framework at Siguiri is represented by northsouth trending $\mathrm{D}_{2}$ strike-slip and reverse faults, anastomosing around and enveloping open to tightly folded domains exposed over an area of 12 by $3 \mathrm{~km}$ (Steyn, 2012). This framework is interpreted by Steyn (2012), to have resulted from progressive deformation within an overall dextral transpressive brittle-ductile shear zone.

Gold mineralisation is hosted mainly within quartz veins, of which one main, and at least three minor sets are distinguished. The main set displays easterly to northeasterly trends and steep southerly dips. Higher grade mineralisation is developed where competent psammitic units coincide with dilational structural sites.

\section{The Kédougou -Kéniéba Inlier}

The Kédougou -Kéniéba Inlier is host to the well-endowed West Mali gold belt, which extends for approximately $180 \mathrm{~km}$ straddling the Mali-Senegal border and which hosts the Loulo, Tabakoto, Sadiola, Yatela, and Gounkoto mines in Mali and the Massawa and Sabodala mines in Senegal (Figure 2). These deposits are spatially related to the crustal-scale Senegal-Mali shear zone, and contain a total gold resource base exceeding $35 \mathrm{Moz}$ (Lawrence et al., 2013a). Despite a long history, (since prehistoric times) of artisanal 
gold production from the belt, modern commercial-scale mining only commenced in 2005.

\section{Loulo}

Loulo is located in the Kayes region of southwestern Mali, 35 km northwest of Kéniéba and approximately $350 \mathrm{~km}$ west of Bamako. The Loulo mining camp comprises the Gara and Yalea deposits and was officially opened in November 2005. Gara and Yalea are both underground mines, with earlier production from open pit operations. By the end of 2012, Loulo had produced 1.93 million ounces of gold. Loulo is owned by Randgold Resources Ltd (80\%) and the State of Mali (20\%).

Extensive soil geochemical surveys carried out in the area in the 1980s by Syndicat Or, a joint venture between the Malian government and the BRGM, led to the discovery of the Gara deposit in 1981. The BRGM interest was acquired by BHP Minerals in 1993. In October 1996, Randgold Resources Ltd acquired BHP's projects in Mali, and carried out an intensive exploration programme which led to the discovery of the Yalea deposit in 1997.

The geology and mineralisation at Loulo is described in detail in Lawrence et al. (2013a and b). The mining camp is located in the eastern part of the Kédougou-Kéniéba inlier within the Kofi Series (Figure 2), a sedimentary package comprising a thrusted and folded sequence of argilites, wackes and platform carbonates. The domainbounding Senegal-Mali shear zone separates the Kofi Series from the Falémé Series, with the latter dominated by high-potassium calcalkaline, metaluminous granitoids, siliciclastic rocks, marbles, undifferentiated volcaniclastic rocks and minor basaltic-andesite lavas.

Gold mineralisation at Loulo is developed east of the SenegalMali shear zone, which initiated as a sinistral transpressional fault during the onset of regional $\mathrm{D}_{2}$ deformation (Milési et al., 1992).

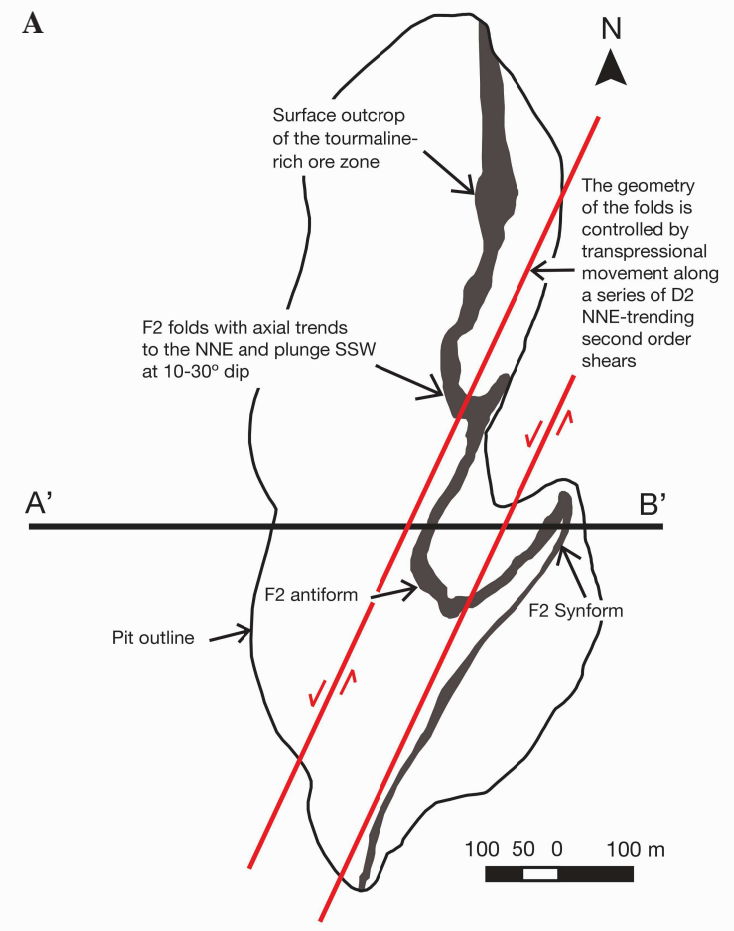

Second-order north-northeast trending shears and related upright folding, developed during advanced $\mathrm{D}_{2}$ transpression. Gold mineralisation is associated with a regional transtensional $\mathrm{D}_{3}$ event (possibly late $\mathrm{D}_{2}$ ); with the development of sinistral north-south and northwest trending higher-order shears (Lawrence et al., 2013b).

Two distinct styles of gold mineralisation are observed, as typified by the Gara and Yalea deposits; with both deposits hosted in calcareous greywackes and calcitic-dolomitic marbles (Lawrence et al., 2013a). At Gara, gold mineralisation is stratiform and hosted in a 5 to 20 metre wide unit of folded and strongly tourmalinised quartz-wacke over a strike length of $1.2 \mathrm{~km}$. The orebody geometry is controlled by north-northeasterly trending folds, related to transpressive $\mathrm{D}_{2}$ deformation, along a series of second-order shears (Figure 9). Garastyle mineralisation occurs as sulphide disseminations or ankeriterich shear vein stockworks, hosted in folded tourmalinized sandstones and breccias, mainly within $2 \mathrm{~km}$ of the Senegal-Mali shear zone. These deposits are characterized by intense multi-stage albitization and tourmalinization (pre-, syn- and post-mineralisation). Gold lodes are iron-rich (sulphide assemblage dominated by nickeliferous pyrite), contain $\mathrm{Cu}-\mathrm{Ni} \pm \mathrm{Co}$, minor and trace sulphides (e.g., chalcopyrite, gersdorffite, pentlandite, cobaltite, millerite), and show consistently high levels of phosphorous-rare earth element-tungsten -bearing phases (apatite, monazite, xenotime, and scheelite). Base metal concentrations show a marked increase in marble host rocks, with the formation of nickeliferous pyrite-cobaltite-clausthalite ores. Gold is mainly hosted in pyrite, as fine, $(<10 \mu \mathrm{m})$ to coarse (up to $350 \mu \mathrm{m}$ ) grains, with Ag concentrations $<1 \mathrm{wt} \%$.

Yalea is located $6 \mathrm{~km}$ to the southeast of Gara, and lies along a third-order shear that strikes north-south over $2 \mathrm{~km}$ (Figure 10A). The shear zone is represented by a 10 to 40 metre wide zone of strongly metasomatized (carbonate \pm albite, sericite-chlorite), brecciated, brittleductile deformed rocks dipping $60^{\circ}$ to the east and becoming subvertical at depth (Figure 10B). Mineralisation is disseminated and

Figure 9. Plan (A) and cross-section (B) of the Gara gold deposit (Lawrence et al., 2013a).

B

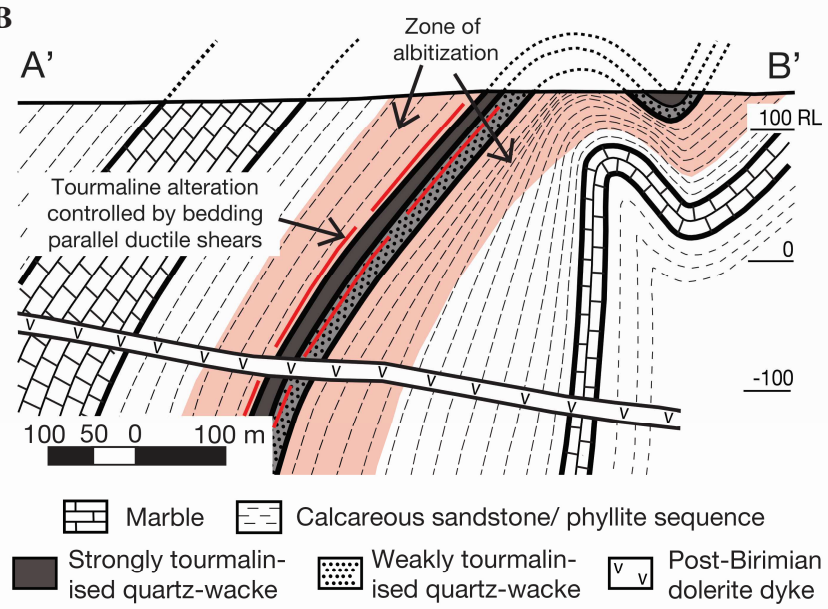


A

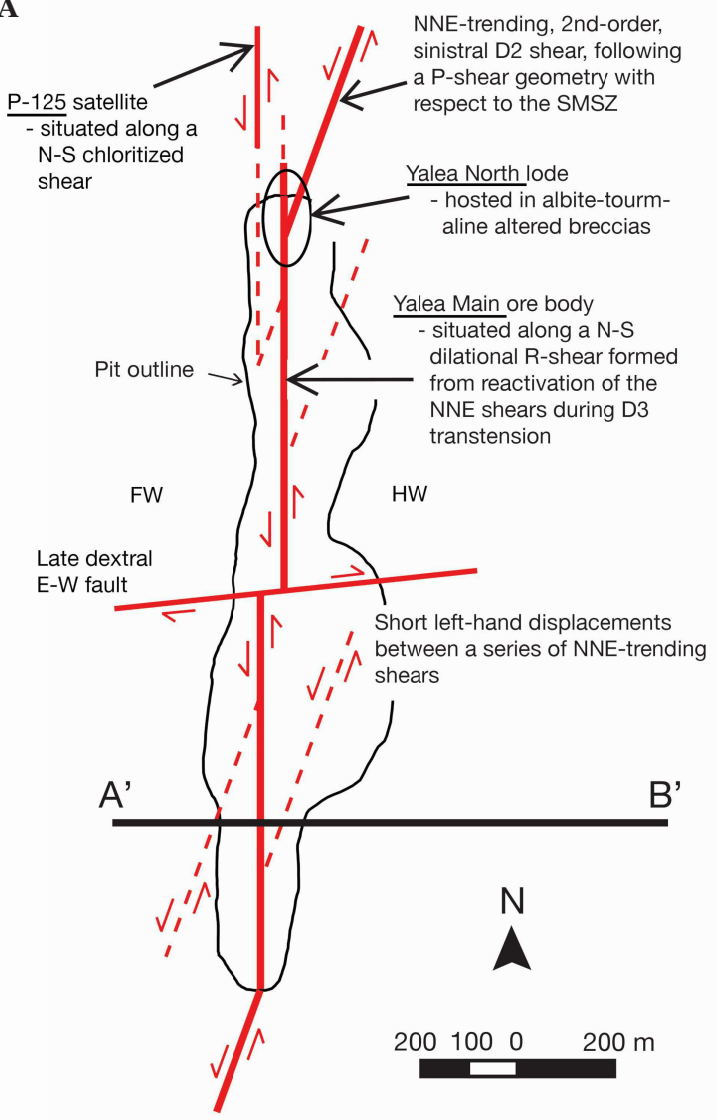

B

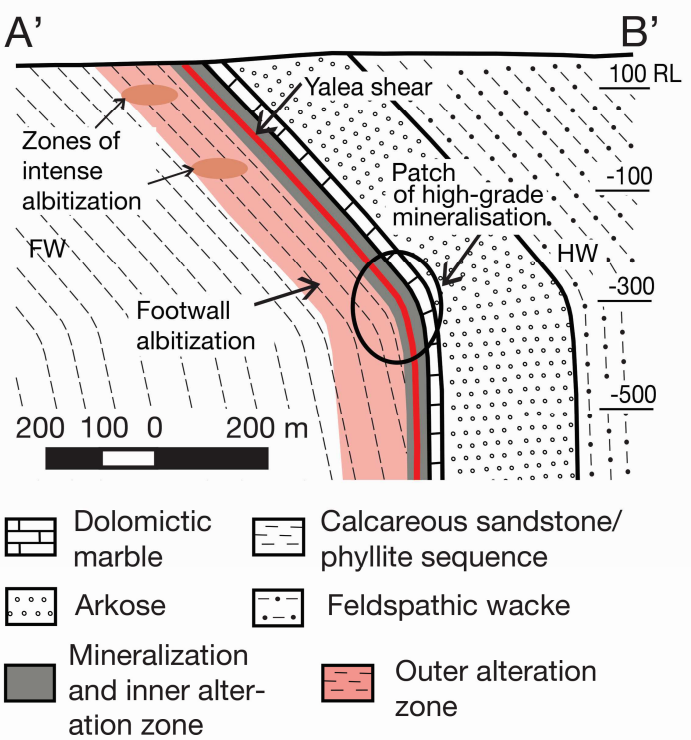

Figure 10. Plan (A) and cross-section (B) of the Yalea gold deposit (Lawrence et al., 2013a).

hosted in the matrix of hydrothermal and tectonic breccias. The alteration halo extends 50 to 100 metres into the wall-rocks.

Yalea-style mineralisation is associated with quartz \pm ankerite vein lodes and disseminated sulphide stringer zones (Lawrence et al., 2013b). Mineralisation occurs along highly altered (tourmalinefree), brittle-ductile shears, up to $8 \mathrm{~km}$ away from the Senegal-Mali shear zone. Alteration is dominated by ankerite \pm albite and later sericite-chlorite. Gold is generally fine-grained $(<20 \mu \mathrm{m})$, with silver contents ranging from 1 to $8 \mathrm{wt} \%$. Arsenic contents are consistently high, with arsenopyrite-pyrite ratios in the order of 70:30. Base metal sulphides, scheelite, and (REE)-phosphates, as observed at Gara, are extremely rare at Yalea. This style of deposit is typical of Birimian gold mineralisation in Ghana, whereas polymetallic iron-boron-rich Gara-style deposits are atypical.

\section{Gounkoto}

The Gounkoto mine is located $19 \mathrm{~km}$ south of Loulo and forms part of the so-called Loulo-Gounkoto mining complex, which represents one of the largest orogenic gold districts in West Africa, outside of Ghana (Figure 1). The geology and mineralisation of the Gounkoto deposit is described in Lambert-Smith et al. (2015).

Gounkoto was a greenfields discovery announced in May 2009 by Randgold Resources Ltd. The target was initially identified from an airborne electromagnetic survey, with subsequent soil sampling defining a $2 \mathrm{~km}$ long north-northwest trending $30 \mathrm{ppb}$ gold in soil anomaly. Follow-up rock chip sampling and trenching confirmed the prospectivity of the target. Reconnaissance drill testing confirmed
Gounkoto as a significant new discovery. The first gold was produced in 2011.

Gounkoto is located south of, and along strike from, the Gara and Yalea deposits at Loulo. As such, it shares a similar geological setting, being located within Kofi Series metasedimentary rocks east of, and proximal to, the Senegal-Mali shear zone.

Gold mineralisation at Gounkoto is hosted in a shear bounded package of strongly albitised sediments, with fine argillaceous sandstone units in the hangingwall and footwall. An unaltered quartz wacke unit below the footwall argillaceous sandstone rocks, marks the furthest westerly extent of mineralisation. The host sedimentary rocks are intruded by numerous monzodiorite dykes.

Gold mineralisation is related to regionally extensive sodic alteration which has resulted in albite-hematite replacement of the host rocks and their subsequent brittle deformation. Albitisation is commonly overprinted by carbonatisation, and the development of chlorite-ankerite-pyrite stringers during the main ore forming hydrothermal event. Strong magnetite and hematite alteration, and associated localised tourmalinisation, is characteristic of the north trending structures at Gounkoto.

The orebody geometry is structurally complex comprising four zones known, from south to north, as the Iron Structure; the Wrench Zone; the Pinch Zone; and the Jog Zone (Figure 11). Simplistically, the deposit is hosted on two left stepping dilational jogs (the Wrench and Jog Zones), between a series of north-northeast trending sinistral shear zones. Discrete north-south and north-northwest trending shears intersect the orebody along its strike. Structural complexities are noted within each of the zones, particularly the Jog Zone, where at least 

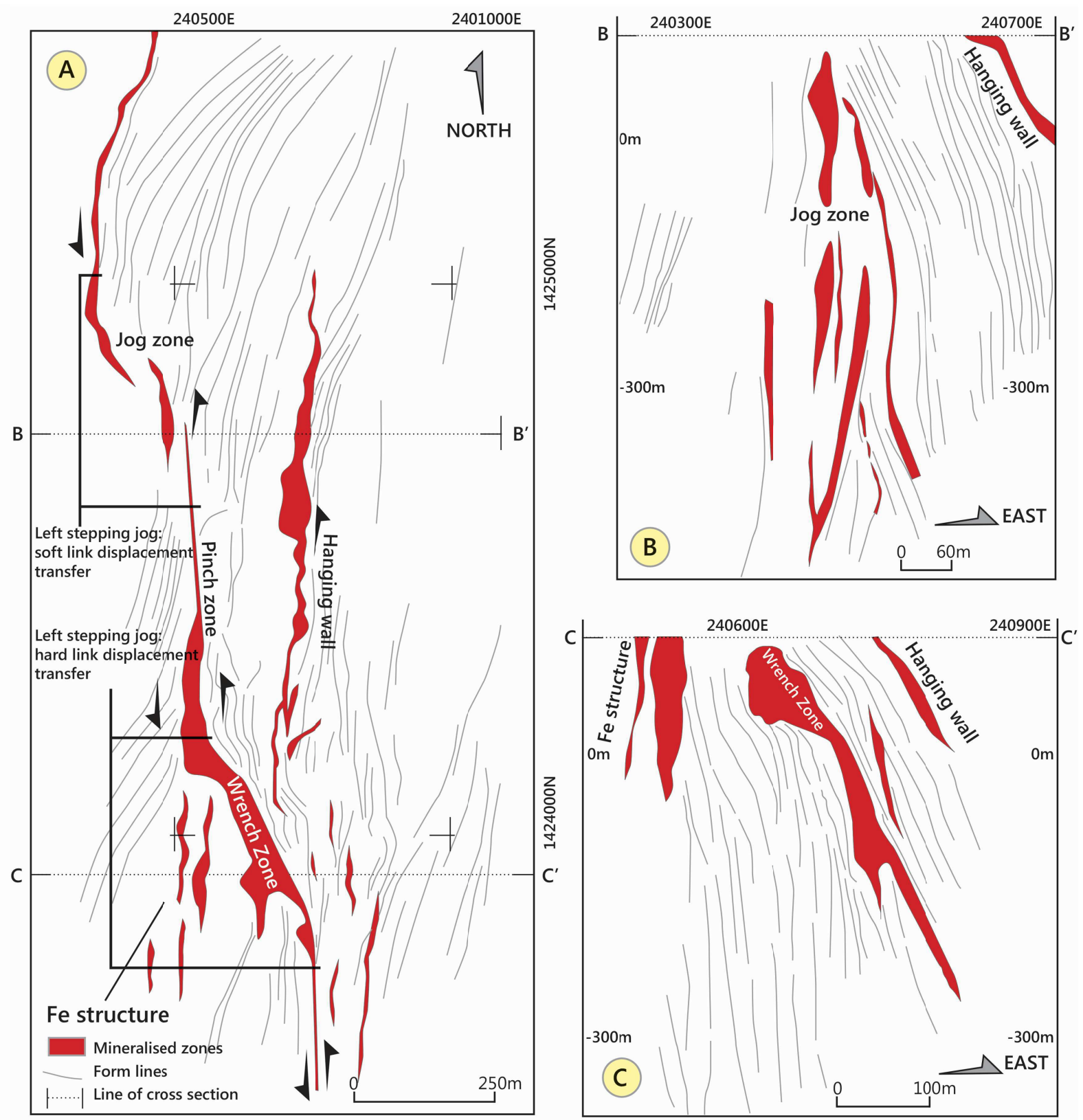

Figure 11. (A) Plan of the Gounkoto deposit showing the orebody geometry at 45 metres (above sea level) and structural form lines showing the sinistral left hand jogs in the Wrench and Jog Zones; $(B)$ cross section of line B-B' showing the geometry of the Jog Zone with several sub-parallel en echelon orebodies and; $(C)$ cross section of line $C$-C'showing the geometry of the Wrench Zone, note the contrasting steep and shallow dips of the Wrench Zone and Fe structure respectively (Source: Lambert-Smith et al., 2015).

three en echelon mineralised shear zones are observed. The Jog Zone hosts some of the highest grade mineralisation at Gounkoto.

Mineralisation styles at Gounkoto are related to prolonged hydrothermal activity and contemporaneous brittle-ductile deformation. A variety of mineralisation styles and textures are observed including shear-hosted sulphide stringers, sulphides in the matrix of hydrothermal breccias, disseminated sulphides overprinting host rock, and rare vein hosted sulphides (Lambert-Smith et al., 2013). Higher grade zones are associated with sulphide stringers and multiply deformed breccias.

Sulphide mineralisation is dominated by pyrite $(\sim 99 \%)$, with arsenopyrite the most abundant accessory sulphide $(<1 \%)$. Minor chalcopyrite and pyrrhotite are present as inclusions within pyrite. Magnetite is common, comprising up to $15 \%$ of the rock in some drillhole intersections and occurs as either inclusions in pyrite or as a late phase replacing it. Native gold and gold tellurides are associated with pyrite, arsenical pyrite and magnetite. Gold grains are present as inclusions within pyrite, in the gangue assemblage, filling fractures within pyrite, or annealed to pyrite. The gold grain size is typically $<30 \mu \mathrm{m}$; however fracture fill grains are up to $200 \mu \mathrm{m}$.

\section{Tabakoto - Kofi Camp}

The Tabakoto gold mine is located $360 \mathrm{~km}$ west of Bamako, 15 $\mathrm{km}$ north of Kéniéba, and approximately $30 \mathrm{~km}$ east of the LouloGounkoto mining complex (Figure 2). The mine is owned $80 \%$ by Endeavour Mining Corporation and 20\% by the Government of Mali. The Tabakoto gold mine comprises the Tabakoto and Kofi Nord mine 
permits and surrounding exploration properties (Figure 12). The Tabakoto permit includes the Tabakoto, Ségala, Djambaye II, Dioulafoundou and Dar Salam deposits (Armstrong et al., 2011). The Kofi property includes a number of known deposits and exploration targets. Together, the Loulo-Gounkoto-Tabakoto-Kofi properties represent a highly gold-endowed district in the eastern sector of the Kédougou-Kéniéba inlier.

Open pit production at the Tabakoto and Ségala deposits commenced in 2005 and 2007 respectively by the operating company Nevsun. Mining proceeded under Avion Gold Corporation from 2009 to 2012 from open pits at Ségala, Tabakoto, Dioulafoundou and Djambaye II, and from underground at Tabakoto. Endeavour Mining Corporation took over operations in 2013.

The mine currently produces from the Tabakoto and Ségala underground operations and from the Kofi C open pit (located $40 \mathrm{~km}$ to the northwest of Tabakoto). In 2014, a total of 127,323 ounces of gold was produced from the operations.

The known gold deposits at Tabakoto are typical of orogenictype structurally controlled deposits (Goldfarb et al., 2005; Groves, et al., 1998). They can also be considered to be related to turbiditehosted gold deposits. The Tabakoto, Segala and Kofi deposits are hosted in metasedimentary rocks of the Kofi Series, comprising mainly turbiditic greywacke and argillite sequences.

The Tabakoto deposit occurs within a north-south trending tight upright anticline, whose axial surface dips steeply to the east (de Hert et al., 2014). A suite of felsic to intermediate dykes intrudes along the length of the core of the anticline and forms the locus of preferential alteration (silica, sericite and/or Fecarbonate), forming competent host rocks. The fold hinge is intersected by a conjugate set of numerous northeast and northwest striking structures. Gold mineralisation is preferentially hosted within silicified dykes and adjacent metasedimentary rocks along the axial trace of the anticline. In addition to north south trending corridors, gold is hosted within subsidiary but intersecting northeast, northwest and easterly trending structures characterized by increased veining, sulphide mineralisation and locally, silicification of the hosting sedimentary units. Gold mineralisation correlates with an increase in quartz and sulphide veining, with pyrite and arsenopyrite as well as minor pyrrhotite and chalcopyrite.

The structural pattern observed at Tabakoto is mimicked on a regional scale.

At Ségala, $6 \mathrm{~km}$ to the northwest of Tabakoto, five mineralised zones striking east-southeast have been defined over a strike of some 350 metres and up to 550 metres vertically, within a mineralised corridor up to 65 metres wide. Mineralisation occurs as coarse $(+1$ $\mathrm{mm}$ ) visible gold quartz carbonate veins and stockworks typically hosted within sheared felsic intrusives and hydrothermally altered metasediments adjacent to intrusives (de Hert et al., 2014). Gold also occurs as extensive wall rock $(\sim 15 \mathrm{~m})$ mineralisation in both the hangingwall and footwall to these felsic intrusives, within altered metasediments comprising silica-sericiteankerite-sulphide assemblages.
Further variations in mineralisation style in the Tabakoto camp are observed at the Djambaye II deposit, where stockwork-style gold mineralisation is hosted within an intrusive, and is associated with albitisation and to a lesser extent silicification and sulphidation (de Hert et al., 2014). Mineralisation has been defined over a strike of some 2,500 metres and is still open to the north, south and at depth. The mineralisation is mostly confined to two dykes, each from 2-5 meters wide. The mineralisation is stockwork style in character, with pyrite and subordinate arsenopyrite and is often associated with quartz veins. High grade zones occur mostly near cross structures.

Although $40 \mathrm{~km}$ northwest of Tabakoto, the Kofi C deposit shares many similarities, including host rock, structural features and style of alteration (de Hert et al., 2014). The Kofi C deposit is structurally controlled and hosted within metasedimentary rocks that have been intruded by a series of narrow dykes. Gold mineralisation is associated with a pyritic quartz vein stockwork. A series of moderately east dipping lenses of mineralisation are observed, which can be traced for approximately 700 metres along strike and up to 275 metres in depth. Individual lenses can range up to 40 to 50 metres in width, with an average width of 10 to 15 metres.

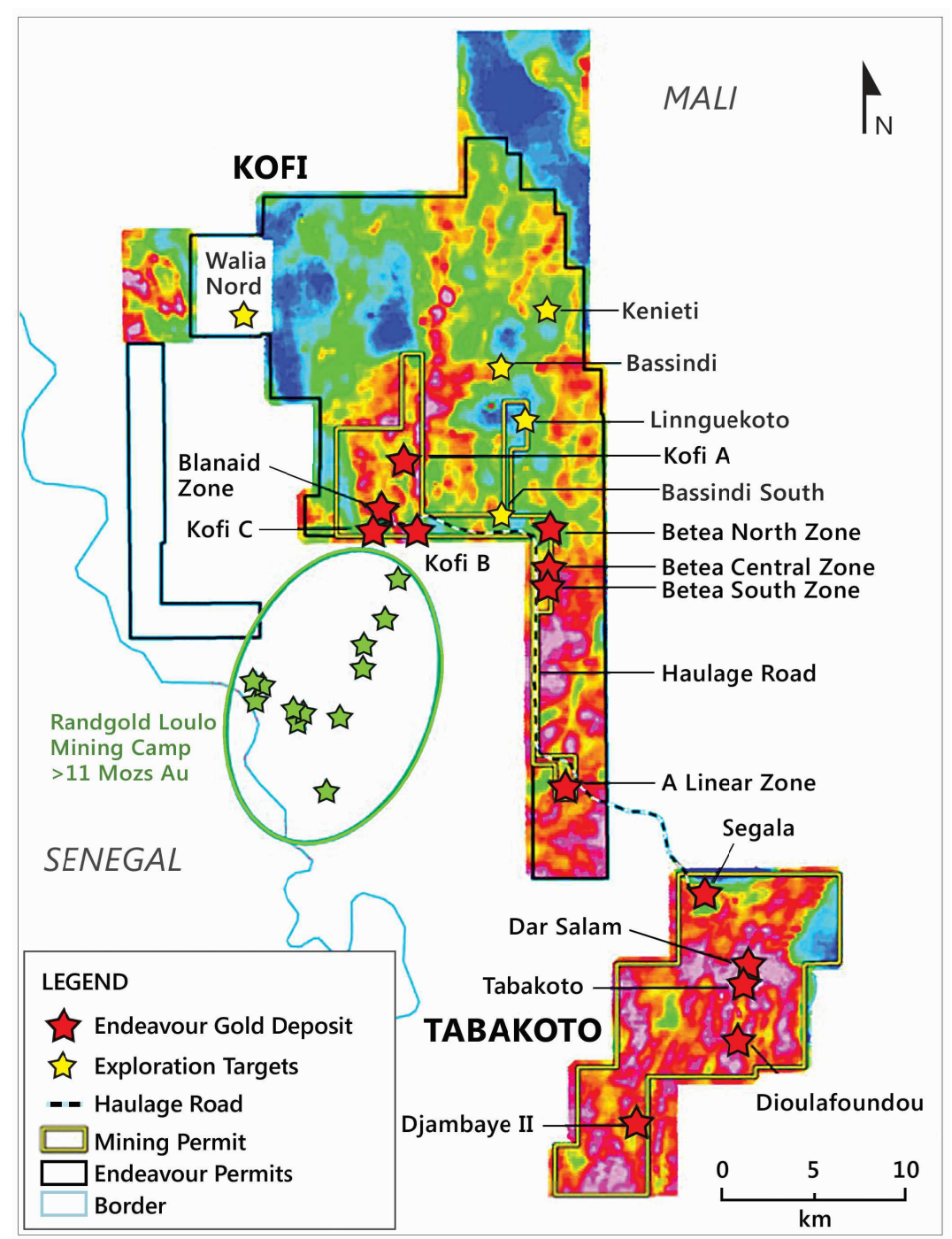

Figure 12. Plan of the Tabakoto-Kofi-Loulo mining camps showing deposits and exploration targets overlain on electromagnetic data (Source: www.endeavour mining.com). 


\section{Sadiola}

The Sadiola mine is located in the northern part of the KédougouKéniéba Inlier, approximately $70 \mathrm{~km}$ south of the town of Kayes, the regional capital (Figure 2). Ownership of the mine is $41 \%$ IAMGOLD, 41\% AngloGold Ashanti, with the Government of Mali holding $18 \%$.

In 1987, a regional geochemical survey rediscovered the deposit when a clear 7 x $3 \mathrm{~km}$ gold-in-soil anomaly was delineated, centred on Sadiola Hill where artisanal workings in saprolitic oxide ore could be followed for 1200 metres along strike. Following extensive exploration and development, the first gold was produced in 1996. Mining is currently carried out from five open pits with a carbon-inpulp processing plant. In 2014 a total of 206,000 ounces of gold were produced at Sadiola.

As is the case in the Loulo-Gounkoto mining camp to the south, the Sadiola deposit is located immediately east of the Senegal-Mali shear zone and is hosted by Kofi Series metasediments that have been intruded by numerous felsic intrusives.

The deposit occurs along the north-northeast striking Sadiola Fracture Zone (SFZ) which is interpreted as a brittle-ductile splay of the Senegal-Mali shear zone, at a sinistral releasing bend (Robins, 2006). The SFZ follows the steeply west dipping contact between Kofi Formation greywacke and meta-pelite to the west and impure carbonates to the east (Figure 13). The SFZ and wallrock are intruded by diorite dykes. Quartz-feldspar-porphyry dykes intrude younger north-northeast striking and steeply west dipping faults and preserve brittle deformational features.

Gold mineralisation occurs in a major flexure of the SFZ over a strike length of $2.5 \mathrm{~km}$ and remains open to the north and south. High-grade gold mineralisation is developed at the intersections of the SFZ with the north-northeast striking splays, resulting in steeply plunging zones within the plane of the SFZ.
Gold mineralisation is hosted within all four principal rock types namely greywacke, impure marble, diorite and quartzfeldspar-porphyry. Mineralisation is spatially associated with calc-silicate, potassic, chlorite-calcite and carbonate alteration whilst the gold occurs in arsenic and antimony dominated sulphide assemblages including arsenopyrite, pyrrhotite, pyrite, stibnite and gudmundite. Primary gold is extremely fine grained, dominantly less than $15 \mu \mathrm{m}$, with rare grains approaching 50 microns.

A characteristic of Sadiola is the deep oxidation (influenced by fracturing) and subsequent development of oxide mineralisation to a depth of $220 \mathrm{~m}$. The bulk of the mineralisation is hosted within marble, which has been decarbonated as a result of the deep oxidation. Mining has mainly exploited soft, oxide ore, since start-up in 1996, with oxide reserves expected to be mined out in 2016. In December 2010, a feasibility study was completed on the mining and processing of the hard sulphide ore at the Sadiola Gold Mine.

In the primary zone, gold is associated with sulphides which are dominated by arsenopyrite (that contains fine-grained gold), pyrite and pyrrhotite, occurring as fine veins and disseminations. The primary mineralisation is accompanied by calc-silicate, potassic (biotite) and carbonate alteration as well as by silicification.

\section{Yatela}

The Yatela gold mine is located $25 \mathrm{~km}$ north of Sadiola (Figure 2 ) and began production in 2001. Mining has been completed from a number of open pits and is scheduled to cease by the end of 2016, following a final cut-back in the Yatela main pit, as well as a new pit north of the Yatela main pit. The deposit is located within $8 \mathrm{~km}$ of the Senegal-Mali Shear Zone.

The geology of the Yatela deposit is described in Masurel et al. (2016) and Hein et al. (2016). Gold mineralisation at Yatela is hosted

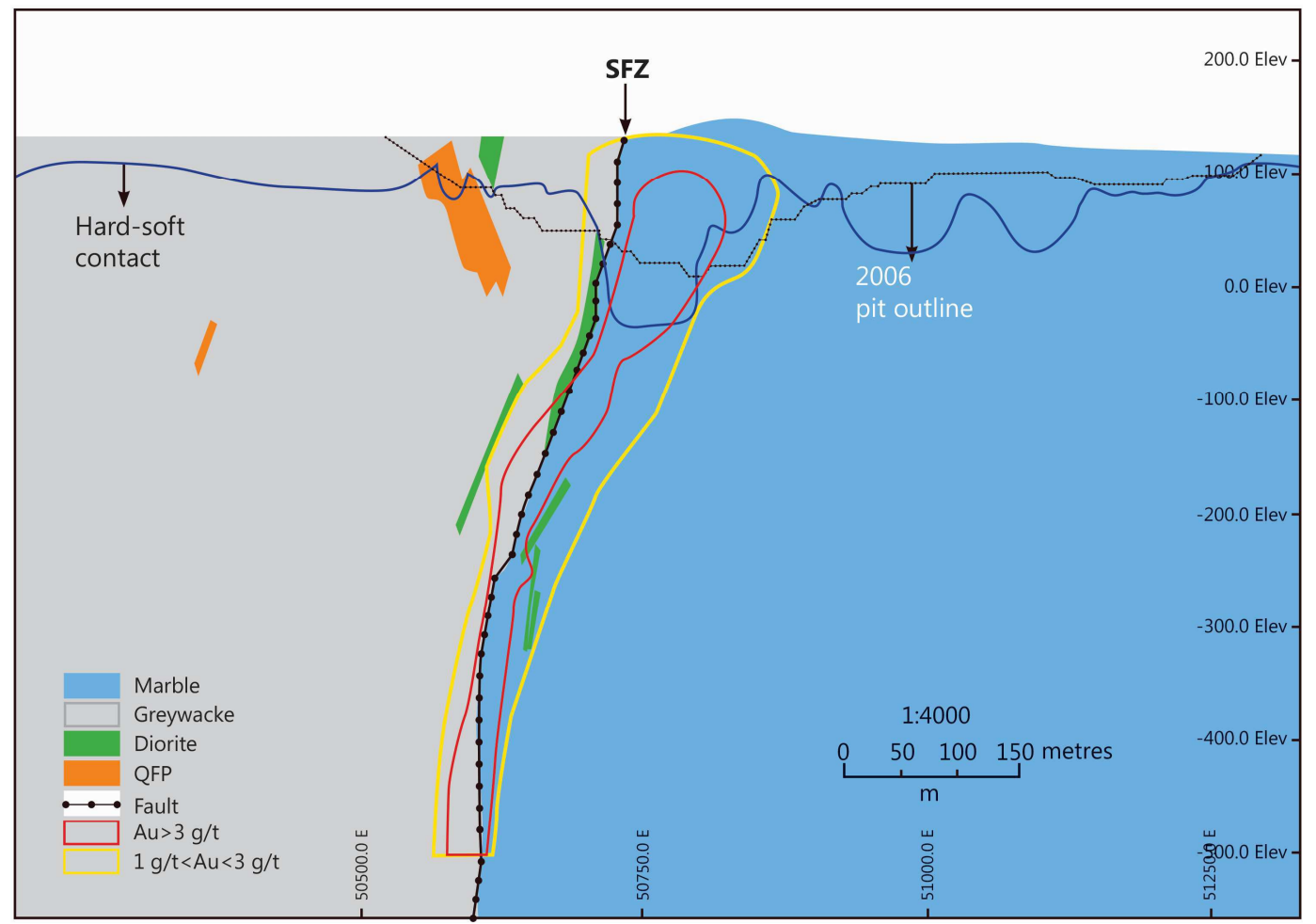

Figure 13. Section through the Sadiola orebody. Mineralisation is focussed along the greywacke-marble contact (Sadiola Fracture Zone) as shown by the gold grade shells. (Source: Robins, 2006). 
in a saprolitic residuum (friable lateritised palaeosols and Aeolian sands) situated above Birimian metamorphosed calcitic and dolomitic marbles that were intruded by diorite. Sub-economic hypogene gold mineralisation is pyrite-rich with abundant chalcopyrite, minor arsenopyrite and accessory $\mathrm{Zn}-\mathrm{Pb}-\mathrm{Sb}$-Fe-Ag-Co-Ni-bearing mineral species (Masurel et al., 2016) and is associated with hydrothermal activity synchronous with emplacement of the diorite (Hein et al., 2016). Post-Birimian surficial dissolution of hydrothermally altered and mineralised host marbles resulted in the creation of troughs, which were draped and infilled with a ferruginous dissolution residue enriched in gold (Masurel et al., 2016). Yatela is unique in the context of West African gold deposit types in that a gold-bearing residuum of economic interest (>1 Moz) is derived from an underlying subeconomic Birimian occurrence, This has implications for the prospectivity of other gold provinces of the West African Craton, where carbonates are present, such as the Siguiri basin in Guinea and the Ity region in western Côte d'Ivoire (Masurel et al., 2016).

\section{Sabodala}

The Sabodala mine is located on the Senegalese side of the Kédougou-Kénieba Inlier, some $650 \mathrm{~km}$ east of the capital Dakar (Figure 2). The mine is owned by Teranga Gold Corporation (90\%) with the Senegalese Government holding (10\%).

The area has only recently been opened for mining and exploration and is emerging as a significant new gold district, with more than 10 Moz in gold resources already reported as being discovered (Chawrun et al., 2014). The Sabodala gold project is the only large-scale gold mine to have come into operation in Senegal and is located within the volcanic-dominated Mako Series of the Kédougou-Kénieba Inlier (Figure 2). The Mako Series is separated from the metasedimentdominated Dialé-Daléma Series to the east, by the Main Transcurrent Shear Zone. The Mako Series is intruded by a series of variably deformed granitoid intrusions. Felsic and intermediate composition dykes are often spatially associated with shear zones hosting gold mineralisation, and locally are host to significant gold mineralisation themselves.

At Sabodala, mafic volcanic rocks with associated sub-volcanic mafic intrusions are interlayered with variably altered ultramafic units and local sedimentary horizons, all within the Mako Series (Chawrun et al., 2014). A large granitic intrusion occupies the northwestern portions of the property. Lithologies generally trend north-northeast to northeast, with steep dips, although local variations are apparent which may be locally important trap sites for mineralisation, especially where units are obliquely intersected and cut by mineralised shear zones.

Principal structures on the Sabodala property form a steeply westnorthwest dipping, north-northeast trending shear zone network which has previously been referred to as the "Sabodala Shear Zone". This includes the Niakafiri, and Masato shear zones, which are high strain zones developed in altered ultramafic units.

The Sabodala deposit is developed over a strike length of at least 600 metres and comprises a network of mineralised shear zones and associated surrounding sets of quartz breccia veins and vein arrays which are discordant to, and cut across, the hosting volcanic stratigraphy. Mineralisation is most intensely focussed in and west of the intersection of shear zone network and crosscuts a mylonitic chert unit. Several shear zone orientations control the position and morphology of gold mineralisation in the deposit.
Gold mineralisation at the Sabodala deposit occurs in a combination of continuous grey quartz shear veins along shear zone surfaces in the Main Flat and Northwest shear zones, in sets of quartzcarbonate-albite-pyrite extension veins, in coalescing extension and shear vein domains which form zones of quartz-carbonate matrix breccia, and in areas of pervasive tan to pink coloured carbonatealbite-sericite-pyrite alteration, which surround and link veins, shear zones and breccias. Multiple generations of veins are evident, with the youngest being the most voluminous and altered.

\section{Theories on the Origin of Mineralisation}

The similarities between Archaean orogenic gold deposits and those of the Birimian, suggest that they share a similar tectonic setting and origin. Gold mineralisation in the Birimian is spatially and temporally associated with polycyclic deformation during the Eburnean Orogeny, and by virtue of a strong structural control, these deposits can be classified as orogenic-type gold deposits as defined by Groves et al. (1998). Most of the known gold deposits are hosted along, or proximal to, major shear zones which often occur at domain boundaries and juxtapose rock types of differing rheological properties. In particular, deposits commonly occur along or near the margins of greenstone belts with metasedimentary sequences, or granitic intrusive belts. In most cases, gold mineralisation is interpreted to have formed by hydrothermal activity accompanying the late stages of the Eburnean Orogeny (Foster and Piper, 1993; Allibone et al., 2002).

In many instances, structural preparation was necessary during the Eburnean $\mathrm{D}_{1}$ event to facilitate metallogenesis during $\mathrm{D}_{2}$ deformation (Tshibubudze, 2015), e.g. the reactivation of major $D_{1}$ structures as transcurrent faults. While peak gold mineralisation is associated with transcurrent $\mathrm{D}_{2}$ deformation at approximately 2.152.10 Ga (Markwitz et al., 2015), some deposits are related to the $\mathrm{D}_{1}$ Eoeburnean (Tangaean) event at approximately 2.19-2.15 Ga (Allibone et al., 2002; Tshibubudze et al., 2009; Hein, 2010; de Kock et al., 2012), which is observed in Ghana (e.g., Wassa), Burkina Faso (e.g., Kiaka, Essakane) and Mali (e.g., Morila) (Markwitz et al., 2015).

Gold mineralisation is associated with sulphidised brittle-ductile shear zones and occurs in two main styles: (1) quartz vein-hosted, in which gold is concentrated within structurally controlled dilational sites including sheeted and stockwork quartz vein systems, fracture arrays, breccias and fold hinges (Foster and Piper, 1993; Béziat et al., 2008), and (2) as disseminated deposits, where gold mainly occurs as disseminated particles in alteration haloes surrounding veins (Béziat et al., 2008). Depositional sites are typically secondary or tertiary structures related to major structures. Albitisation and carbonatisation are common hydrothermal alteration assemblages, as are pyrite and/ or arsenopyrite precipitation, which appears to be important for gold deposition (Béziat et al., 2008).

Weathered or supergene deposits such as occur at Siguiri, Ity and Yatela, are an exception to the norm, but have important implications for exploration targeting, where gold-bearing residuum of potential economic interest may overly underlying primary (possibly subeconomic) mineralisation.

\section{Summary of Resources and Reserves}

The significant gold endowment of the West African region is apparent in Table 1, which summarises the Mineral Resource and 
Table 1. Gold Resource and Reserve status summary for selected West African gold mines and advanced projects (mostly stated as at 31 December 2014)

\begin{tabular}{|c|c|c|c|c|c|c|c|c|c|c|c|c|}
\hline \multirow[t]{2}{*}{$\begin{array}{l}\text { Mine/ } \\
\text { Project }\end{array}$} & \multirow[t]{2}{*}{ Status } & \multirow[t]{2}{*}{ Country } & \multicolumn{3}{|c|}{$\begin{array}{l}\text { Total Measured + } \\
\text { Indicated Resources }\end{array}$} & \multicolumn{3}{|c|}{$\begin{array}{l}\text { Total Inferred } \\
\text { Resources }\end{array}$} & \multicolumn{3}{|c|}{$\begin{array}{c}\text { Total } \\
\text { Reserves }\end{array}$} & \multirow{2}{*}{\begin{tabular}{|c}
$\begin{array}{c}2014 \\
\text { Production }\end{array}$ \\
$\begin{array}{c}\text { Gold } \\
\text { (oz) }\end{array}$
\end{tabular}} \\
\hline & & & $\begin{array}{c}\text { Tonnes } \\
\text { (Mt) }\end{array}$ & $\begin{array}{c}\text { Grade } \\
(\mathrm{g} / \mathrm{t})\end{array}$ & $\begin{array}{l}\text { Gold } \\
\text { (Moz) }\end{array}$ & $\begin{array}{c}\text { Tonnes } \\
(\mathrm{Mt})\end{array}$ & $\begin{array}{c}\text { Grade } \\
(\mathrm{g} / \mathrm{t})\end{array}$ & $\begin{array}{l}\text { Gold } \\
\text { (Moz) }\end{array}$ & $\begin{array}{l}\text { Tonnes } \\
\text { (Mt) }\end{array}$ & $\begin{array}{c}\text { Grade } \\
(\mathrm{g} / \mathrm{t})\end{array}$ & $\begin{array}{l}\text { Gold } \\
\text { (Moz) }\end{array}$ & \\
\hline Loulo & Operating Mine & Mali & 52.0 & 4.30 & 7.100 & 20.0 & 3.20 & 2.100 & 33.0 & 4.60 & 4.900 & 639,219 \\
\hline Gounkoto & Operating Mine & Mali & 27.5 & 4.24 & 3.800 & 7.5 & 3.20 & 0.800 & 22.0 & 4.40 & 3.200 & \\
\hline Tabakoto & Operating Mine & Mali & 19.0 & 3.00 & 1.839 & 17.6 & 2.80 & 1.582 & 6.7 & 3.70 & 0.807 & 127,323 \\
\hline Sadiola & Operating Mine & Mali & 115.1 & 1.78 & 6.595 & 5.5 & 1.60 & 0.291 & 57.4 & 2.10 & 3.840 & 206,000 \\
\hline Morila & Operating Mine & Mali & 14.0 & 0.60 & 0.200 & 11.0 & 0.60 & 0.200 & 13.0 & 0.70 & 0.300 & 110,272 \\
\hline Syama & Operating Mine & Mali & 28.4 & 2.56 & 2.305 & 13.1 & 2.14 & 0.909 & 29.1 & 2.50 & 2.379 & 342,773 \\
\hline Sabodala & Operating Mine & Senegal & 43.3 & 1.22 & 1.700 & 18.4 & 0.93 & 0.550 & 4.5 & 1.50 & 0.210 & 211,823 \\
\hline Ity & Operating Mine & Côte d'Ivoire & 59.1 & 1.50 & 2.920 & 9.7 & 1.50 & 0.458 & 30.3 & 1.66 & 1.602 & 82,000 \\
\hline Tongon & Operating Mine & Côte d'Ivoire & 34.0 & 2.50 & 2.700 & 12.0 & 2.70 & 1.000 & 30.0 & 2.30 & 2.200 & 227,103 \\
\hline Agbaou & Operating Mine & Côte d'Ivoire & 13.9 & 2.50 & 1.109 & 2.1 & 2.30 & 0.154 & 11.5 & 2.50 & 0.926 & 146,757 \\
\hline Essakane & Operating Mine & Burkina Faso & 124.4 & 1.20 & 4.702 & 14.8 & 1.30 & 0.628 & 108.8 & 1.10 & 3.886 & 368,900 \\
\hline Inata & Operating Mine & Burkina Faso & 31.7 & 1.75 & 1.780 & 29.2 & 1.61 & 1.513 & 5.3 & 1.92 & 0.326 & 86,037 \\
\hline Taparko & Operating Mine & Burkina Faso & 0.1 & 2.08 & 0.007 & 8.7 & 2.36 & 0.659 & 6.5 & 2.77 & 0.578 & 112,000 \\
\hline Mana & Operating Mine & Burkina Faso & 42.4 & 2.02 & 2.757 & 12.9 & 2.83 & 1.179 & 23.1 & 3.01 & 2.240 & 234,300 \\
\hline Youga & Operating Mine & Burkina Faso & 17.0 & 1.50 & 0.812 & 2.8 & 1.60 & 0.141 & 3.5 & 1.80 & 0.202 & 76,561 \\
\hline Kalsaka & Closed Mine & Burkina Faso & 1.2 & 1.70 & 0.064 & 2.3 & 1.50 & 0.108 & 1.7 & 1.50 & 0.080 & 31,030 \\
\hline Siguiri & Operating Mine & Guinea & 150.2 & 0.77 & 3.730 & 74.9 & 1.01 & 2.450 & 95.1 & 0.73 & 2.230 & 340,000 \\
\hline Lefa & Operating Mine & Guinea & 99.8 & 1.17 & 3.741 & 49.4 & 1.12 & 1.787 & 66.4 & 1.22 & 2.600 & 205,100 \\
\hline Bonikro & Operating Mine & Côte d'Ivoire & 35.7 & 1.47 & 1.640 & 3.0 & 2.10 & 0.197 & 24.0 & 1.30 & 1.000 & 119,970 \\
\hline New Liberty & Operating Mine & Liberia & 9.8 & 3.63 & 1.143 & 5.7 & 3.20 & 0.593 & 8.5 & 3.40 & 0.924 & N/A \\
\hline Kalana & Advanced Project & Mali & 20.6 & 4.12 & 2.730 & 1.2 & 4.83 & 0.180 & & & & N/A \\
\hline Yanfolila & Advanced Project & Mali & 8.2 & 3.30 & 0.870 & 11.9 & 2.50 & 0.949 & & & & N/A \\
\hline Fekola & Advanced Project & Mali & 61.6 & 2.16 & 4.281 & 9.1 & 1.68 & 0.490 & 49.2 & 2.4 & 3.718 & N/A \\
\hline Kobada & Advanced Project & Mali & 36.0 & 1.05 & 1.210 & 39.0 & 1.00 & 1.205 & & & & N/A \\
\hline Massawa & Advanced Project & Senegal & 35.0 & 2.60 & 3.000 & 24.0 & 2.10 & 1.700 & 21.0 & 3.10 & 2.000 & N/A \\
\hline Yaoure & Advanced Project & Côte d'Ivoire & 104.1 & 1.54 & 5.100 & 47.7 & 1.41 & 2.200 & 70.4 & 1.18 & 2.660 & N/A \\
\hline Sissingué & Advanced Project & Côte d'Ivoire & 16.0 & 1.70 & 0.880 & 1.1 & 1.70 & 0.063 & 5.5 & 2.40 & 0.429 & N/A \\
\hline Kiaka & Advanced Project & Burkina Faso & 124.1 & 0.99 & 3.938 & 27.3 & 0.93 & 0.815 & & & & N/A \\
\hline Banfora & Advanced Project & Burkina Faso & 31.4 & 2.20 & 2.200 & 25.0 & 1.80 & 1.400 & & & & N/A \\
\hline Houndé & Advanced Project & Burkina Faso & 37.8 & 2.10 & 2.546 & 3.2 & 2.60 & 0.273 & 30.6 & 2.1 & 2.073 & N/A \\
\hline Karma & Advanced Project & Burkina Faso & 75.2 & 1.08 & 2.621 & 65.3 & 1.13 & 2.361 & 33.2 & 0.9 & 0.949 & N/A \\
\hline Bamboré & Advanced Project & Burkina Faso & 139.9 & 0.98 & 4.561 & 18.4 & 1.22 & 0.723 & 59.9 & 0.8 & 1.465 & N/A \\
\hline Yaramoko & Advanced Project & Burkina Faso & 1.6 & 15.80 & 0.810 & 0.8 & 10.26 & 0.278 & 2.0 & 11.8 & 0.759 & N/A \\
\hline Dugbe & Advanced Project & Liberia & 41.8 & 1.51 & 2.031 & 10.2 & 1.32 & 0.435 & & & & N/A \\
\hline Baomahun & Advanced Project & Sierra Leone & 38.4 & 1.81 & 2.240 & 6.6 & 2.52 & 0.540 & 23.3 & 1.62 & 1.200 & N/A \\
\hline Komahun & Advanced Project & Sierra Leone & 3.7 & 4.69 & 0.550 & 2.6 & 4.08 & 0.340 & & & & N/A \\
\hline AVERAGE & & & & 1.66 & 90.212 & & 1.58 & 31.251 & & 1.76 & 49.683 & $3,667,168$ \\
\hline
\end{tabular}

Reserve status (mostly as at 31 December 2014) for selected gold mines and advanced projects, as published by various companies. The table includes the Mineral Resource classification and the 2014 gold production, where applicable. A total of $3.7 \mathrm{Moz}$ was produced from the major West African mines in 2014.

\section{Future of the Mineral Field and Exploration Potential}

As a region, West African is currently arguably the best address for the gold mining and exploration industry in Africa with a number of new mines having been developed over the last ten years and numerous advanced projects in several countries throughout the region. These projects are either under construction or close to implementation and are poised to deliver well over a million ounces of new gold production within the next three to five years (Tassell, 2015).

Ghana is the largest gold producer in the region, but it has seen a decline in production since peaking in 2012. Mali has recently become the third biggest gold producer in Africa and has been the destination of choice for gold exploration in the West African region in recent years. The more important advanced gold projects in Mali include Yanfolila, Kalana and Fekola. 
Burkina Faso is regarded by some as the fastest growing gold producer in Africa, with eight new mines having been commissioned over the past six years, despite having seen less than 15 years of modern mineral exploration. The excellent geological potential is derived from extensions of the major gold-bearing Birimian greenstone belts of Ghana and Côte d'Ivoire that continue northward into Burkina Faso. Advanced projects due to come on line include Yaramoko, Karma, Houndé and Bomboré.

Côte d'Ivoire is regarded as the new gold frontier in West Africa and one of the least explored areas in the region, despite being underlain almost exclusively by Birimian rocks. The important nearproduction projects are Yaoure (arguably the largest gold development project in West Africa) and Sissingué.

Large parts of the West African region remain under-explored relative to similar gold provinces elsewhere. Apart from the references to the above countries, several other countries in the region have significant gold endowments and exploration potential, including Liberia, Guinea, Senegal, Mauritania and Niger.

Thick laterite cover and poor exposure across much of the region has hindered exploration in the past; however tools such as high resolution airborne geophysical datasets and RAB drilling have opened up new areas to exploration. The exploration potential of the West African Craton has also been significantly enhanced through the results of the WAXI programme. New data and improved understanding relating to gold mineralisation in the region will assist exploration companies in focussing their activities in areas of maximum prospectivity.

\section{Acknowledgements}

This paper benefitted from an earlier unpublished review of West African gold compiled by Kim Ncube-Hein of the University of the Witwatersrand and Vanessa Markwitz of the University of Western Australia. These authors, together with John Miller of the University of Western Australia, have compiled a subsequent review of West African mineral deposits, currently in press with Precambrian Research.

The authors are also grateful to two reviewers whose comments and suggestions, particularly in respect of recent published WAXI work, resulted in improvements to, and updating of, the final manuscript. Sue Frost-Killian is thanked for her assistance in the compilation and drafting of Figure 1.

\section{References}

Allibone, A., Teasdale, J., Cameron, G., Etheridge, M., Uttley, P., Soboh, A., Appiah-Kubi, J., Adanu, A., Arthur, R., Mamphey, J., Odoom, B., Zuta, J., Tsikata, A., Pataye,F., and Famiyeh, S. (2002). Timing and structural controls on gold mineralisation at the Bogoso Gold Mine, Ghana, West Africa. Economic Geology, 97, 949-969.

Armstrong, T., Puritch, E., Yassa, A., Dudek, D. and Bradfield, A. (2011). Technical Report on the Tabakoto Mining Operations, Mali, West Africa. NI 43-101 Technical Report prepared for Avion Gold Corporation, 291pp.

Ayensu, E.S., (1997). Ashanti Gold: The African Legacy of the World's Most Precious Metal. Published by the Marshall Editions Development Ltd, 200pp.

Baratoux, L., Metelka, V., Naba, S., Jessell, M.W., Gregoire, M. and Ganne, J. (2011). Juvenile Paleoproterozoic crust evolution during the Eburnean orogeny ( 2.2-2.0 Ga), western Burkina Faso. Precambrian Research, 191, 18-45.

Barth, M.G., Rudnick, R.L., Carlson, R.W., Horn, I., and McDonough, W.F. (2002). Re-Os and U-Pb geochronological constraints on the eclogite-tonalite connection in the Archean Man Shield, West Africa. Precambrian Research, 118 (3-4), 267-283.

Bessoles, B. (1977). Géologie de 1'Afrique. Le craton OuestAfricain. Mémoires BRGM, Paris, 88, 402pp.

Béziat, D., Siebenaller, L., Salvi, S and Chevalier, P. (2015). A weathered skarn-type mineralization in Ivory Coast: The Ity gold deposit. Ore Geology Reviews, http://dx.doi.org/10.1016/ j.oregeorev.2015.07.011.

Béziat, D., Dubois, M., Debat, P., Nikiéma, S., Salvia, S., Tollon, F. (2008). Gold metallogeny in the Birimian craton of Burkina Faso (West Africa). Journal of African Earth Sciences, 50, 215-233.

Body, K.J., Mpfariseni, M., Cunningham, G.I., Bosc, R., Perez, P., Baker, J., Gauthier, D., Larochelle, P and Sangam, H.P. (2015). Technical Report for the Ity Gold Mine, Côte d'Ivoire, West Africa. NI 43-101 Technical Report compiled for Endeavour Mining Corporation, 277pp.

Chawrun, P., Nakai-Lajoie, P., Mann, P., Martin, J.C., and Riles, A. (2014). Technical Report - Sabodala Gold Project. NI 43-101 Technical Report prepared for Teranga Gold Corporation, 352pp.

De Hert., G., Harris, K., Alyoshin, M., Duke, V., Roux, A., Puritch, E., and Yassa, A. (2014). Technical Report and Mineral Resource and Reserve Update for the Tabakoto Gold Mine, Mali, West Africa. NI 43-101 Technical Report prepared for Endeavour Mining Corporation. 280pp.

de Kock, G.S., Armstrong, R.A., Siegfried, H.P., and Thomas, E. (2011). Geochronology of the Birim Supergroup of the West African craton in the Wa-Bolé region of west central Ghana: implications for the stratigraphic framework. Journal of African Earth Sciences, 59, 1-40.

de Kock, G.S., Théveniaut, H., Botha, P.M.W., and Gyapong, W. (2012). Timing the structural events in the Palaeoproterozoic Bolé-Nangodi belt terrane and adjacent Maluwe basin, West African craton, in central-west Ghana. Journal of African Earth Sciences, 65, 1-24.

Diene, M., Fullgraf, T., Diatta, F., Gloaguen, E., Gueye, M. and Ndiaye, P.M. (2015). Review of the Senegalo-Malien shear zone system - Timing, kinematics and implications for possible $\mathrm{Au}$ mineralisation styles. Journal of African Earth Sciences, 112B, 485-504.

Egal, E., Thieblemont, D., Lahondere, D., Guerrot, C., Costea, C.A., Iliescu, D., Delor,C., Goujou, J.C., Lafon, J.M., Tegyey, M., Diaby, S., and Kolie, P. (2002). Late Eburnean granitization and tectonics along the western and northwestern margin of the Archean Kénéma-Man domain (Guinea, West Africa Craton). Precambrian Research, 117, 57-84.

Eisenlohr, B.N. and Hirdes, W. (1992). The structural development of the early Proterozoic Birimian and Tarkwaian rocks of southwest Ghana, West Africa. Journal of African Earth Sciences, 14 (3), 313-325.

Endeavour Mining website. (2015). http://www.endeavourmining. com

Ennih, N. and Liegeois, J.-P. (Eds). (2008a). The Boundaries of the West African Craton (IGCP485). Geological Society of London Special Publication 297, 536pp.

Ennih, N. and Liegeois, J.-P. (2008b). The boundaries of the West African Craton with a special reference to the basement of the Moroccan metacratonic Anti-Atlas Belt. In: Ennih, N. and Liegeois, J.-P. (Eds). The Boundaries of the West African Craton (IGCP485). Geological Society of London Special Publication 297, 1-17. 
Feybesse, J.-L., Billa, M., Guerrot, C., Duguey, E., Lescuyer, J.L., Milési, J.P., and Bouchot,V. (2006). The Palaeoproterozoic Ghanaian province. Geodynamic model and ore controls, including regional stress modelling. Precambrian Research, 149, 149-196.

Foster, R.P., and Piper, D.P. (1993). Archaean lode gold deposits in Africa: crustal setting,metallogenesis and cratonization. Ore Geology Reviews, 8, 303-347.

Gewald, J. B. (2010). Gold The True Motor Of West African History: An Overview Of The Importance Of Gold In West Africa And Its Relations With The Wider World. Rozenburg Quarterly Magazine.

Goldfarb, R.J., Baker, T., Dube, B., Groves, D.I., Hart, C.J.R., and Gosselin, P. (2005). Distribution, character, and genesis of gold deposits in metamorphic terranes: Economic Geology $100^{\text {th }}$ Anniversary Volume, 407-450.

Groves, D.I., Goldfarb, R.J., Gebre Mariam, M., Hagemann, S.G., and Robert, F. (1998). Orogenic gold deposits: A proposed classification in the context of their crustal distribution and relationship to other gold deposit types. Ore Geology Reviews, 13, 7-27.

Hammerbeck, E.C.I., Veselinovic-Williams, M. \& Frost-Killian, S. (2008). International metallogenic map of Africa (digital version). Council for Geoscience, Pretoria, South Africa.

Hammond, N. Q., Robb, L., Foya, S., and Ishiyama, D. (2011). Mineralogical, fluid inclusion and stable isotope characteristics of Birimian orogenic gold mineralization at the Morila Mine, Mali, West Africa. Ore Geology Reviews, 39, 218-229.

Hein, K.A.A. (2010). Succession of structural events in the Goren greenstone belt (Burkina Faso): implications for West African tectonics. Journal of African Earth Sciences, 56, 83-94.

Hein, K.A.A., Matsheka, I.R., Bruguier, O., Masurel, Q., Bosch, D., Caby, R and Monié, P. (2015). The Yatela gold deposit: 2 billion years in the making. Journal of African Earth Sciences, 112B, 548-569.

Hirdes, W., Davis, D.W., and Eisenlohr, B.N. (1992). Reassessment of Proterozoic granitoid ages in Ghana on the basis of $\mathrm{U} / \mathrm{Pb}$ zircon and monazite dating. Precambrian Research, 56, 89-96.

Hirdes, W., and Davis, D.W. (2002). U-Pb Geochronology of Paleoproterozoic rocks in the southern part of the KédougouKéniéba inlier, Senegal, West Africa: Evidence for diachronous accretionary development of the Eburnean Province. Precambrian Research, 118, 83-99.

Holliday, J. (2014). Exploration - still the engine that drives Randgold. Presentation for London Investor Day Webcast - 21 November 2014.

http://www.avocetmining.com/ Date accessed: 30/11/2015.

http://www.endeavourmining.com/ Date accessed: 12/11/2015.

http://www.iamgold.com/ Date accessed: 30/11/2015.

http://www.nordgold.com/ Date accessed: 30/11/2015.

http://www.iamgold.com/ Date accessed: 29/10/2015.

Hubert, H. (1934). Carte Geologique,Afrique Occidentale Française et Togo. Echelle 1,6M. Available for viewing at. http:// yves.cordelle.free.fr/CDFamilialAvant Sept1939/Photos4/1934cAlbertH-AOFgeologique.jpg.

Jébrak, M. and Marcoux, E. (2008). Geology of Mineral Resources. Published by the Mineral Deposits Division of The Geological Association of Canada, 668pp.

Jessell, M., Amponsah, P.O., Baratoux, L., Asiedu, D.K., Loh, G.K. and Ganne, J. (2012). Crustal-scale transcurrent shearing in the Paleoproterozoic Sefwi-Sunyani-Comoé region, West Africa. Precambrian Research, 212-213, 155-168.

Jessell, M.W and Liégeois, J.-P. (2015). 100 years of research on the West African Craton. Journal of African Earth Sciences, http:// dx.doi.org/10.1016/j.afrearsci.2015.10.008.
Kitson, A.E. (1918). Annual Report for 1916/17. Gold Coast Geological Survey, Accra, Ghana.

Kouamelan, A.N., Delor, C., and Peucat, J.-J. (1997). Geochronological evidence for reworking of Archean terrains during the Early Proterozoic (2.1 Ga) in the western Cote d'Ivoire (Man Rise-West African Craton). Precambrian Research, 86 (34), 177-199.

Lambert-Smith, J. S., Lawrence, D. M., Herbert. S., Vargas, C. A, Boyce, A. J., and Treloar, P. J. (2015). The Gounkoto Au deposit, West Africa: constraints on ore genesis and volatile sources from petrological, fluid inclusion and stable isotope data. Ore Geology Reviews. http://dx.doi.org/10.1016/j.oregeorev.2015.10.025).

Lawrence, D.M. (2013). The Paragenesis of the Tongon Gold Deposit, North Côte d'Ivoire: Implications for Au Skarn Mineralisation. Randgold Resources Internal Company Report, 26pp.

Lawrence, D.M.; Treloar, P.J., Rankin, A.H., Harbidge, P. and Holliday, J. (2013a). The Geology and Mineralogy of the Loulo Mining District, Mali, West Africa: Evidence for Two Distinct Styles of Orogenic Gold Mineralization. Economic Geology, 108, 199227.

Lawrence, D.M., Treloar, P.J., Rankin, A.H., Boyce, A., and Harbidge, P. (2013b). A fluid inclusion and stable isotope study at the Loulo mining district, Mali, West Africa: Implications for multifluid sources in the generation of orogenic gold deposits. Economic Geology, 107, 229-257.

Ledru, P., Pons, J., Milési, J.P., Feybesse, J.L., and Johan, V. (1991). Transcurrent tectonics and polycyclic evolution in the Lower Proterozoic of Senegal-Mali. Precambrian Research, 50, 337-354.

Leube, A., Hirdes, W., Mauer, R., and Kesse, G.O. (1990). The Early Proterozoic Birimian Supergroup of Ghana and some aspects of its associated gold mineralisation. Precambrian Research, 46, 139165.

Markwitz, V., Hein, K.A.A. and Miller, J. (2015). Compilation of West African mineral deposits: Spatial distribution and mineral endowment. Precambrian Research.http://dx.doi.org/10.1016/ j.precamres.2015.05.028.

Masurel, Q., Miller, J., Hein, K.A.A., Hanssen, E., Thébaud, N., Ulrich, S., Kaisin, J., and Tessougue, S. (2016). The Yatela gold deposit in Mali, West Africa: The final product of a long-lived history of hydrothermal alteration and weathering. Journal of African Earth Sciences. 113, 73-87.

Matsheka, I.R., and Hein, K.A.A. (2011). Character, morphology and origin of gold from the selected mines in the Yatela and Sadiola goldfield, Mali, West Africa. In: Poster Presentation to the WAXI Sponsors Meeting, Ouagadougou, Burkina Faso, 28 March to 1 April 2011

McFarlane, C.R.M., Mavrogenes, J., Lentz, D., King, K., Allibone, A., and Holcombe, R. (2011). Geology and intrusion-related affinity of the Morila gold mine, southeast Mali. Economic Geology, 106, 727-750.

Metelka, V., Baratoux, L., Naba, S. and Jessell, M.W. (2011). A geophysically constrained litho-structural analysis of the Eburnean greenstone belts and associated granitoid domains, Burkina Faso, West Africa. Precambrian Research, 190, 48-69.

Milési, J-P., Ledru, P., Feybesse, J-L., Dommanget, A., and Marcoux, E. (1992). Early Proterozoic ore deposits and tectonics of the Birimian orogenic belt, West Africa. Precambrian Research, 58, 305-344.

Morel, S.W. (1979). The geology and mineral resources of Sierra Leone. Economic Geology, 74, 1563-1576.

Nordgold. (2013). Burkina Faso Analyst Vist-Taparko Gold Mine (http://www.nordgold.com/upload/iblock/101/ Presentation\%20for\%20analysts\%20Taparko\%20site\%20visit.pdf. Date accessed: 30/11/2015). 
Oberthür, T., Weiser, T., Amanor, J.A. and Chryssoulis, S.L. (1997). Mineralogical siting and distribution of gold in quartz veins and sulfide ores of the Ashanti mine and other deposits in the Ashanti belt of Ghana: genetic implications. Mineralium Deposita, 32, 2-15.

Olson, S.F., Diakite, K., Ott, L, Guindo, A., Ford, C.R.B, Winer, N., Hanssen, E., Lay, N., Bradley, R., and Pohl, D. (1992). Regional setting, structure, and descriptive geology of the Middle Proterozoic Syama gold deposit, Mali, West Africa. Economic Geology, 87, 310-331.

Perrouty, S., Aillères, L., Jessell, M.W., Baratoux, L. and Bourassa Y. (2012). Revised Eburnean geodynamic evolution of the goldrich Ashanti Belt, Ghana, with new field and geophysical evidence of pre-Tarkwaian deformations. Precambrian Research, 204-205, 12-39.

Peters, L. (2013). The volcanology, geochemistry and metallogenic potential of the Goren volcano-sedimentary belt in northeast Burkina Faso. MSc Thesis. University of the Witwatersrand, 155pp.

Pohl, D. (1998). A decade of change - mineral exploration in West Africa. Paper presented at the SAIMM Symposium: Mining in Africa '98. SAIMM Journal, 98, 311.

Randgold Resources website. (2015). http://www.randgold resources.com.

Robins, S.P. (2006). The quantification of grade uncertainty, and associated risk, and their influence on pit optimisation for the Sadiola Deep Sulphide prefeasibility project. A research project submitted to the Faculty of Engineering and the Built Environment, University of the Witwatersrand, Johannesburg, in partial fulfilment of the requirements for the degree of Master of Science in Engineering. 139pp.

Roux, A., Woodman, K., Harris, K. and Alyoshin, M. (2015). Technical Report: Mineral Resource and Reserve Update for the Agbaou Gold Mine, Cote d'Ivoire, West Africa. NI 43-101 Technical Report prepared for Endeavour Mining Corporation. 129 pp.

Sanogo, K., Sidebe,S., Dembele, M., and Coulibaly, N. (1987). Etude archéologique de la zone Syama-Bananso, cercle de Kadiolo:

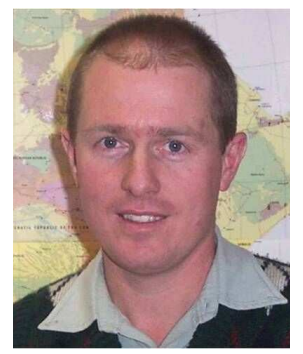

Mike Robertson holds an MSc degree in Geology from the University of the Witwatersrand, and is currently a Principal Consultant with The MSA Group in Johannesburg. Mike's experience of 25 years has focused largely on gold and base metal exploration with an emphasis on orogenic gold deposits in southern, eastern and western Africa as well as the Middle East. His main area of interest is the application of applied structural geology to understanding controls on ore genesis and exploration targeting.
Bamako, Mali, Inst. Sci. Humaines, 29pp.

Sims, J. (2014). Tasiast Project, Mauritania, NI 43-101 Technical Report prepared for Kinross Gold Corporation, 253pp.

Smith, A.J.B., Henry, G. and Frost-Killian, S. (this volume). A review of the Birimian Supergroup- and Tarkwaian Group-hosted gold deposits of Ghana.

Steyn, J.G. (2012). Structural geology and controls of gold mineralisation in the Siguiri Mine, Guinea, West Africa. MSc Thesis. University of Stellenbosch. 147pp.

Stuart, H. (2010). Technical report on the Tasiast gold mine, Islamic Republic of Mauritania. NI 43-101 Technical Report prepared for Red Back Mining Inc., 102pp.

Tassell, A. (2015). Gold resurgent in West Africa. Modern Mining, June 2015, 11 (6), 34-43.

Tshibubudze, T. (2015). Integrated strato-tectonic, U-Pb geochronology and metallogenic studies of the OudalanGorouol volcano-sedimentary Belt (OGB) and the Gorom-Gorom granitoid terrane (GGGT), Burkina Faso and Niger, West Africa ( $\mathrm{PhD}$ thesis). University of the Witwatersrand Johannesburg, 292pp.

Tshibubudze, T. and Hein, K. A. A. (2015). Gold mineralisation in the Essakane goldfield in Burkina Faso, West African craton. Ore Geology Reviews, http://dx.doi.org/10.1016/j.oregeorev.2015. 10.030 .

Tshibubudze, T., Hein, K. A. A., Marquis, P. (2009). The Markoye Shear Zone in NE Burkina Faso, Journal of African Earth Sciences, 55, 245-256.

Villeneuve, M. (2008). Review of the orogenic belts on the western side of the West African Craton: the Bassarides, Rokelides and Mauritanides, in Ennih, N., and Liégeois, J.P., eds., The boundaries of the West African Craton: Geological Society of London Special Publication 297, 169-201.

Villeneuve, M., and Cornée, J.J. (1994). Structure, evolution and paleoceanography of the West African Craton and bordering belts during the Neoproterozoic. Precambrian Research, 69, 307-326.

WAXI. (2013). Confidential Final Report, P934A West African Exploration Initiative. Stage 2, 924pp. (with 917 pages of appendices).

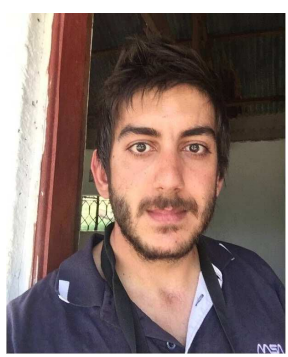

Luke Peters holds an MSc in Geology from the University of the Witwatersrand and was involved in the second phase of the Amira sponsored West African Exploration Initiative (WAXI) (2011 to 2013). Luke has been involved in regional and detailed geological mapping in various Birimian greenstone belts throughout Burkina Faso and Mali. His main areas of interest include vulcanology, structural and geochemical analyses used to delineate localised tectonic settings. Luke is currently an Exploration Geologist at The MSA Group which comprises the largest team of independent geologists on the African continent. 